\title{
Improving California's Safe Drinking Water and Toxic Enforcement Act Scientific Advisory Panel Through Regulatory Reform
}

\author{
Kenneth John Shaffer $\uparrow$
}

This Comment examines the regulations governing California's Safe Drinking Water and Toxic Enforcement Act, Proposition 65. The author argues that the current regulations are founded on an incorrect assumption-that the Panel can reach decisions based solely on scientific facts, independent from subjective political value judgments. In response to this error on the part of the state officials, the Comment proposes a series of regulatory changes, centered around providing the Panel with a balanced membership, protecting the Panel from improper influences that might bias its conclusions, and implementing consistent scientific standards and administrative procedures to ensure that the Panel serves as a reliable and impartial forum. These changes should enhance the Panel's ability to make both scientific and regulatory decisions in a "trans-scientific" decisionmaking environment.

\section{INTRODUCTION}

The advancement of modern technology, with its often complex and uncertain effects on society, has made government dependent on the expertise of independent scientific advisors. ${ }^{1}$ During the last few decades, policymakers increasingly have relied on the advice of hundreds of scientific advisory committees. These committees, staffed with scientists, doctors, and engineers, drawn from both academia and the private

$\dagger$ A.B. 1986, Stanford University; J.D. 1989, Boalt Hall School of Law, University of California, Berkeley.

1. See Brooks, The Scientific Advisor, in The Presidential Advisory System 40, 41 (T. Cronin \& S. Greenberg eds. 1969); Note, Procedures for Decisionmaking Under Conditions of Scientific Uncertainty: The Science Court Proposal, 16 HARV. J. ON LEGIS. 443, 454-55 (1979) (anthored by Jeffrey N. Martin).

The term "scientific advisory committees" as used herein refers to committees consisting solely of members with technical expertise. While government officials also utilize "mixed" committees consisting of both scientists and lay persons, their use is beyond the scope of this Comment. For further discussion of "mixed" committees, see Ashford, Advisory Committees in OSHA and EPA, infra note 2, at 76-77 (interpreting the Federal Advisory Committee Act as requiring a "fair balance" of viewpoints on federal advisory committees, including both scientists and lay persons); Martin, The Proposed "Science Court," 75 Mrch. L. REv. 1058, $1067-69$ (1977) (discussing disadvantages of mixed advisory committees). 
sector, ${ }^{2}$ have assisted government decisionmakers in addressing difficult scientific issues in areas such as health care, national defense, and environmental protection. ${ }^{3}$

One such committee is California's Safe Drinking Water and Toxic Enforcement Act Scientific Advisory Panel, ${ }^{4}$ a recent yet very important addition to that state's efforts to regulate the use and disposal of hazardous substances. This twelve-member group of scientists identifies carcinogens and reproductive toxicants and advises state officials on general issues relating to their regulation. The Panel's purpose, however, is not only to provide officials with needed scientific expertise, but also, ostensibly, to insure that regulatory decisions are based on scientific fact rather than political opinion. ${ }^{5}$ According to one state official, the Panel has "real authority to make decisions based on science that could affect the lives of all Californians." 6

The Panel's membership, duties, and operating procedures are governed by a set of regulations promulgated by California's Health and Welfare Agency. ${ }^{7}$ Agency officials contend that the regulations ensure the Panel is a well qualified decisionmaking body providing state officials

2. For additional background information on the science advisory committee system, see Ashford, The Role of Advisory Committees in Resolving Regulatory Issues Involving Science and Technology: Experience from OSHA and the EPA, in LAW AND SCIENCE IN COLLABORATION 165 (J. Nyhart \& M. Carrow eds. 1983) [hereinafter Ashford, The Role of Advisory Committees]; Ashford, Advisory Committees in OSHA and EPA: Their Use in Regulatory Decisionmaking, 9 ScI. TECH. \& HuM. VAlues 72 (1984) [hereinafter Ashford, Advisory Committees in OSHA and EPA]; Cardozo, The Federal Advisory Committee Act in Operation, 33 ADMIN. L. REV. 1, 37-40 (1981); Gage \& Epstein, The Federal Advisory Committee System: An Assessment, 7 ENVTL. L. REP. 50,001 (1977); Perl, The Scientific Advisory System: Some Observations, in SCIENCE, TECHNOLOGY, AND National Policy 262 (T. Kuehn \& A. Porter eds. 1981).

3. See, e.g., National Defense Authorization Act for Fiscal Years 1988 and 1989, Pub. L. No. 100-180, § 227, 101 Stat. 1019, $1057-59$ (1987) (codified as amended at 10 U.S.C.A. $\$ 2407$ (West Supp. 1989)) (funding development of the Strategic Defense Initiativc); Toxic Substances Control Act, Pub. L. No. 94-469, 90 Stat. 2003 (1976) (codified as amended at 15 U.S.C. $\$ \S 2601-2609$ (1988)) (establishing testing and regulatory standards for hazardous substances); Prcventive Health Amendments of 1984, Pub. L. No. 98-555, 98 Stat. 2854 (1984) (authorizing grants for AIDs rescarch and preventive education); see also National Science and Technology Policy, Organization, and Priorities Act of 1976, Pub. L. No. 94-282, 90 Stat. 459 (1976) (codified as amended at 42 U.S.C. $\S \S 6601-6671$ (1982)) (creating the Office of Science and Technology Policy within the executive branch).

4. CAL. Code of Regs. tit. 22, §§ 12301-12305 (1989). The Safc Drinking Water and Toxic Enforcement Act of 1986, commonly known as Proposition 65, was enacted by California voters through the initiative process on November 4, 1986. Cal. HeAlTH \& SAFETY Code $\$ \S 25249.5-$ 25249.13 (West Supp. 1989). The term "Proposition 65" is used throughout this Comment to identify the Act's statutory provisions.

5. See L.A. Times, Mar. 15, 1987, pt. I, at 30, col. 2 (quoting Governor Deukmejian as saying: "What we are doing is turning this decision over to the scientists, to the experts . . .."). .

6. Sacramento Bee, Feb. 28, 1987, at A1, col. 2 (statement of Thomas E. Warriner, Deputy Secretary of the California Health and Welfare Agency).

7. See Cal. Code of Regs. tit. 22, §§ 12301-12305 (1989). 
with accurate, unbiased scientific advice and information. ${ }^{8}$ Many critics disagree, however, and charge that the regulations have made the Panel a highly pohticized and sometimes meffective decisionmaking body whose decisions seriously threaten both public health and the state's economic welfare. ${ }^{9}$

This Comment examines whether California has in fact created an advisory board that provides the state with scientifically sound and unbiased advice and inforniation, and considers how state officials could amend the regulations under which it operates to promote better scientific and regulatory decisionmaking. Part I briefly reviews the regulations and the statutory provisions under which they were enacted. Part II critiques the fundamental assumption underlying the regulationsthat the Panel can operate apart from the political processes, basing its decisions solely on objective scientific facts rather than on subjective political considerations. The unphications of this erroneous assumption on the Panel's membership, viewpoints, and decisionmaking procedures are illustrated in Parts III through V, respectively, through a detailed examination of the regulations' key provisions. These Parts propose specific amendments to enable the Panel to provide a better decisioumakmg forum for implementing the state's toxics policies.

The Current Statutory and Regulatory Structure Governing the ScIENTIFIC AdVisory PANel

\section{A. Proposition 65: The Safe Drinking Water and Toxic Enforcement Act}

In order to examine California's Science Advisory Panel, it is first necessary to look briefly at the regulatory scheine under which it was estabhished. On November 4, 1986, California voters overwhelmingly approved Proposition $65,{ }^{10}$ the Safe Drinking Water and Toxic Enforce-

8. See California Health and Welfare Agency, Final Statement of Reasons, 22 California Code of Regulations Division 2, Safe Drinking Water and Toxic Enforcement Act of 1986, R-48-87, at 35 (1988) [hereinafter Statement of Reasons] (on file with author); see also Kizer, Warriner \& Book, Sound Science in the Implementation of Public Policy: A Case Report on California's Proposition 65, 260 J. AM. MED. A. 951 (1988); Totten, Controversial Proposition 65 Provokes Industry Outrage, 'Quiet Compliance' as it Marks Second Anniversary as Law, 13 Chem. Reg. Rep. (BNA) No. 5, at 169 (May 5, 1989) (statements by Panel Executive Secretary Dr. Stephen Book defending HWA's regulations).

9. See L.A. Times, June 30, 1989, pt. I, at 29, col. 3; Meyerhoff, Toxics Law: An Effort to Comply or Obstruct?, L.A. Times, Jan. 3, 1988, pt. V, at 5, col. 4.

10. Proposition 65 was approved by $63 \%$ of those voting. San Francisco Chron., Nov. 5, 1986, at A1, col. 6 . 
ment Act. ${ }^{11}$ Placed on the 1986 general election ballot as an initiative, ${ }^{12}$ Proposition 65 was spawned out of growing concerns over the dangers posed by carcinogens and reproductive toxicants to public health and, in particular, to sources of drinking water. ${ }^{13}$ Although a number of federal and state laws designed to alleviate this threat already were in place, ${ }^{14}$ California voters apparently perceived these measures as inadequate, ${ }^{15}$ and in response enacted a sweeping set of statutory provisions designed to protect the public and the environment from exposures to hazardous substances.

Proposition 65 establishes a comprehensive regulatory structure of discliarge limitations and riglit-to-know provisions centered around two

11. Cal. Health \& SAfety Code $\$ \S 25180.7,25189.5,25192,25249.5-25249.13$ (West Supp. 1989).

12. Under the California Constitution, proposed legislation may be placed on the general ballot by citizen petition and adopted by a majority of the voters. CAL. CONST. art. II, $\S \S 8,10$. This process eliminates the need to secure support for the measure from either the legislature or the Governor's office. In fact, Governor George Deukmejian was an outspoken opponent of Proposition 65's passage. See L.A. Times, Nov. 5, 1986, pt. I, at 29, col. 4.

13. In a report issued just one year before the Proposition's enactment, the California Economic Development Commission estimated that exposure to hazardous substances contributed to as many as 2,500 cancer deaths within the state annually. CALIFORNIA Commission For Economic Development, Poisoning Prosperity: The Impact of Toxics on California's ECONOMY at $x$ (1985). The Commission warned that, if unabated, toxic chemicals potentially could cause economic losses in excess of $\$ 40$ billion dollars during the next decade from lost work, medical expenses, and cleanup costs. Id. at iv, 29-112.

14. See, e.g., Federal Water Pollution Control Act Amendments of 1972, Pub. L. No. 92-500, 86 Stat. 816 (1972) (codified as amended at 33 U.S.C. $\$ \S 1254 a-1387$ (1982)) (establishing maximum permissible standards for discharge of effluents into public waterways and sources of drinking water); Federal Safe Drinking Water Act, Pub. L. No. 93-523, 88 Stat. 1660 (1974) (codified as amended at 42 U.S.C. $\$ \S 300$ fo $300 \mathrm{j}-9$ (1982)) (establishing standards for certain toxicants contained in drinking water at a "level at which . . no known or anticipated adverse effects on the health of persons occur and which allows an adequate margin of safety," 88 Stat. at 1663, $\S 1412$ (b)(1)(B)); Resource Conservation and Recovery Act of 1976 (RCRA), Pub. L. No. 94-580, 90 Stat. 2795 (1976) (codified as amended at 42 U.S.C. $\$ \$ 6901-6987$ (1982)) (regulating hazardous waste disposal); Comprehensive Environmental Response, Compensation, and Liability Act of 1980 (CERCLA), Pub. L. No. 96-510, 94 Stat. 2767 (1980) (codified as amended at 42 U.S.C. $§ \S 9601-$ 9657 (1982)) (establishing standards governing private and public responses to "rcleases" of hazardous and toxic substances); see also California's Porter-Cologne Water Quality Control Act, ch. 482, 1969 Cal. Stat. 1045 (codified as amended at CAL. WATER Code $\$ \S 13000-13999.16$ (West 1971 \& Supp. 1989)) (creating a system of water use protection); Note, California's Toxics Initiative: Making it Work, 39 Hastings L.J. 1195, 1198 n.29 (1988) (authored by Judith A. DeFranco) (listing further relevant statutes).

15. In a poll conducted by the Sierra Club in coordination with the Institute of Politics at the University of Southern California, 8 out of 10 California voters polled responded favorably to imposing strict limitations on the discharge of hazardous chemicals into water supplies and requiring businesses to post warnings of potential exposure to such chemicals, even though informed that this might entail "considerable costs to businesses and consumers." 2 THE POLLING REP. No. 2, at 1 (1986) quoted in Nossaman, Guthner, Knox \& Elliot, and R. Carrick, Surviving Proposition 65: A Basic GuIdebook to the SAfE Drinking Water and Toxic ENFORCEMENT ACT OF 1986, at 5 (1987) [hereinafter NOSSAMAN, GUTHNER]. 
basic statutory requirements. ${ }^{16}$ First, it prohibits a "person in the course of doing business"17 from knowingly discharging or releasing a "significant amount" of a known carcinogen or reproductive toxicant into a source of drinking water. ${ }^{18}$ Second, it prohibits such persons from knowingly exposing an individual to a known carcinogen or reproductive toxicant without first providing a "clear and reasonable warning."19 The Proposition exempts from these right-to-know and discharge requireinents exposures to carcinogens that pose "no significant risk" assuming lifetime exposure to the level in question and exposures to reproductive toxicants at levels less than one thousandth of those known adversely to affect humans. The burden, however, is on toxic polluters to prove that these exemptions apply. ${ }^{20}$ Proposition 65 thus creates the umque presumption that an exposure presents a public health hazard unless proven otherwise. ${ }^{21}$ Failure to overcome this presumption may subject an individual to civil penalties of up to $\$ 2,500$ for each day of noncomphance. ${ }^{22}$

Although Proposition 65 speaks broadly of regnlating all substances "known to the state to cause cancer or reproductive toxicity," it in fact applies only to those substances included on an official list compiled by the Governor. ${ }^{23}$ At a minimuin, this list inust include a number of substances identified as hazardous by the National Toxicology Program

16. For further analysis of the Act's provisions, see generally SENATE OfFICE OF RESEARCH, Cal. Legislature, ANalysis of Proposition 65 (1986) [hereinafter ANalysis of Proposition 65] (authored by Bruce Jennings); Proposition 65 Implementation: Joint Hearing Before the Senate Toxics and Public Safety Management Committee and the Senate Budget and Fiscal Review Committee No. 3, State of Califormia (1987); Nossaman, GuTHNER, supra note 15; Note, Proposition 65's Right-to-Know Provision: Can it Keep its Promise to California Voters?, 14 Ecology L.Q. 685 (1987) (authored by Melinda Haag); Note, supra note 14.

17. Proposition 65 excludes from its definition of "person in the course of doing business" any person employing less than 10 individuals, as well as certain government entities. CAL. HEALTH \& SAFETY CODE § 25249.11(b) (West Supp. 1989).

18. Id. $\S \S 25249.5,25249.9(\mathrm{~b})(1)$.

19. Id. $\S 25249.6$.

20. Id. $\S 25249.10(\mathrm{c})$.

21. See Nossaman, GuthNer, supra note 15, at 2 ("Proposition 65 is revolutionary in concept, creating a new approach to toxic substance management.").

22. Cal. Health \& Safety CoDe $\S 25249.7$ (West Supp. 1989). This section authorizes enforcement actions by the Attorney General, any state district attorney, or "any person in the public interest." Id. $\S 25249.7$ (c)-(d). The authorization of private party actions has sometimes been referred to as the "bounty hunter" provision, as it entitles victorious parties to $25 \%$ of any penalty collected. Id. § 25192(a)(2); see also Nossaman, GUTHNER, supra note 15, at 11; Kizer, Warriner \& Book, supra note 8, at 951.

Proposition 65 also raises maximum penalties for criminal violations of California's toxic substance control laws from $\$ 50,000$ to $\$ 250,000$ per day for each violation, and authorizes imprisonment for up to 36 months. CAL. Health \& SAFETY CoDE $§ 25189.5$ (West Supp. 1989).

23. Cal. Health \& SafeTY Code $§ 25249.8$ (West Supp. 1989). 
(NTP), ${ }^{24}$ the International Agency for Research on Cancer (IARC), ${ }^{25}$ and the Occupational Safety and Health Administration (OSHA). ${ }^{26}$ In addition, the Proposition requires the Governor to update the list at least once every year to include substances that fall into any one of three categories: (1) substances that the "state's qualified experts" have determined to be "clearly shown through scientifically valid testing according to generally accepted principles to cause cancer or reproductive toxicity", ${ }^{27}$ (2) substances that "a body considered to be authoritative by [the state's qualified] experts has formally identified ... as causing cancer or

24. The National Toxicology Program (NTP) is operated by the U.S. Public Health Service and publishes an annual report identifying known and suspected carcinogens. See, e.g., NationAL Toxicology Program Public Information Office, U.S. Pub. Health Serv., Fourth Annual Report on Carcinogens: Summary (1985). The NTP list is reproduced in Nossaman, GuthNer, supra note 15 , at B-9 to B-13.

The relationship between the NTP's carcinogen identification process and Proposition 65 is currently unclear. Because Proposition 65 only applies to "known" carcinogens and reproductive toxicants, the Governor has included only a portion of all substances identified by NTP on his official list of hazardous substances. A California Court of Appeal, however, has recently ordered Governor Deukmejian to include as many as $\mathbf{2 0 0}$ additional substances classified as hazardous by the NTP, by the International Agency for Research on Cancer, and by the Occupational Safety and Health Administration. See infra note 26.

25. As with the NTP, the World Health Organization's International Agency for Research on Cancer (IARC) compiles hists of substances known or suspected to be carcinogens. See, e.g., California Health and Welfare agency, Guidelines for Chemical Carcinogen Risk Assessments AND Their SCIENTIFIC RATIONALE at B-27 to B-31 (1985) (reproducing the IARC lists) (also available in Nossaman, GuTHNER, supra note 15, at B-2 to B-8).

26. In what has turned out to be one of its most controversial provisions, Proposition 65 requires that, at a minimum, the Governor's list include those substances "identified by reference" in CAL. LAB. CODE § 6382(b)(1), (d) (West Supp. 1989), part of California's Hazardous Substance Information and Training Act of 1980 (HSITA). CAL. HEALTH \& SAFETY CODE § 25249.8(a) (West Supp. 1989). The relevant portions of HSITA, in turn, incorporate those substances listed as human or animal carcinogens by IARC as well as any additional substances within the scope of the federal Hazard Communication Standard. CAL. LAB. CoDE $\S$ 6382(b)(1), (d) (West Supp. 1989). The referenced federal standard, 29 C.F.R. $§ 1910$ (d)(4) (1988), includes those substances listed by NTP and OSHA as known carcinogens and reproductive toxicants.

The scope of the minimum listing requirement became a source of controversy when Governor Deukmejian included only 26 carcinogens and 3 reproductive toxicants on his first list issued on February 27, 1987. See CAL. CODE OF REGS. tit. 22, $\$ 12000$ (1989) (indicating those substances included on the Governor's initial list); see also "Short Lists" and "Dead Bodies": Violating the Body Politic, 7 CAL. REg. L. REP. No. 2, at 15 (1987); L.A. Times, Mar. 17, 1987, pt. I, at 3, col. 3; Sacramento Bee, Feb. 28, 1987, at A1, col. 3. A coalition of labor, consumer, and environmental groups filed suit immediately thereafter, demanding that the Governor include approximately 200 additional substances identified by IARC, NTP, and OSHA as known carcinogens or reproductive toxicants in laboratory animals. L.A. Times, Feb. 28, 1987, pt. I, at 1, col. 2. In July 1989 a California Court of Appeal affirmed a Superior Court order requiring the Governor to add the 200 substances to his list. AFL-CIO v. Deukmejian, 212 Cal. App. 3d 425, 260 Cal. Rptr. 479 (1989). The impact of this decision is unclear, however, since the Panel had added nearly all of the substances ordered to be listed during the two years while the case was pending. Id., 260 Cal. Rptr. at 488 n.10.

27. Cal.. Health \& SAFETY CODE $§ 25249.8(b)$ (West Supp. 1989). Although the question is not entirely clear, it appears that the "experts" " identifications of hazardous substances have the force of law. See infra notes 54-61 and accompanying text. 
reproductive toxicity"; $; 2$ or (3) substances that a state or federal agency "has formally required ... to be labeled or identified as causing cancer or reproductive toxicity." 29

While Proposition 65 grants the "state's qualified experts" a central role in identifying known hazardous substances, it does not specify what individuals or organizations should serve in that capacity. Instead, the ineasure authorizes the Governor to identify the state's experts and to consult with them "as necessary to carry out his duties ...."30 To comply with this provision, Governor George Deukmejian turned to Califorma's Health and Welfare Agency (HWA) for guidance in designating the state's experts. ${ }^{31}$ The Governor seemed confident im HWA's ability to interpret the Proposition's requirenents, having previously designated HWA as the "lead agency" for the implementation process $^{32}$ and placed it in charge of a special "working group" staffed by high ranking officials from a number of other state agencies. ${ }^{33}$

After less than two inonths of dehberations and almost no public debate, ${ }^{34}$ the working group recommended that HWA create a scientific advisory committee and that the Governor designate it as the "state's quahified experts." Proposition 65 does not explicitly authorize the creation of an advisory committee, but its broad language clearly does not preclude one either. ${ }^{35}$ The members of the working group believed that, because of the highly technical nature of Proposition 65's listing require-

28. Cal. Health \& Safety Code $§ 25249.8(b)$ (West Supp. 1989).

29. Id. The Proposition does not specifically mention the removal of substances from the list, but this power has been inferred from its lauguage. L.A. Times, Jan. 30, 1988, pt. I, at 30, col. 2 ("The governor will be free to add or delete chemicals from the list.").

30. Cal. Health \& SAFETY CODE $§ 25249.8$ (d) (West Supp. 1989).

31. See Prop. 65 Coordinator Discusses Role, AleRT: California Chamber of Commerce, Jan. 16, 1987, at 3 (interview with Thomas Warriner, HWA Deputy Secretary).

32. Under Proposition 65, the lead agency has the power to "adopt and modify regulations, standards, and permits as necessary to conform with and implement" its provisions. CAL. HEALTH \& SAFETY CODE $§ 25249.12$ (West Supp. 1989). While this power need not include participation in the selection of the state's experts, apparently the Governor thought it useful to seek HWA's assistance because of the highly technical nature of the Proposition's statutory requirements.

33. Cal. Exec. Order No. D-61-87, Cal. Admin. Notice Reg. 87, No. 4-Z, at B-15 (Jan. 23, 1987). The working group consisted of the directors or secretaries of the Business, Transportation, and Housing Agency, the Environmental Affairs Agency, the Department of Food and Agriculture, the Department of Iudustrial Relations, the Resources Agency, and the Department of Health Services. Id.

34. Because HWA and the Governor's office generally kept its plans for implementing the Act secret, it is impossible to know when the idea for the Panel first originated. See San Francisco Chron., Dec. 8, 1986, at 1, col. 3. The first public disclosure of the Panel's creation did not oceur until January, 1987, barely a month prior to its commencing operation. AlerT: CALIFORNIA CHAMBER OF COMMERCE, supra note 31 , at 3.

35. In spite of statements to the contrary by government officials and the popular press, Proposition 65 did not require the Governor to designate the Panel as the "state's qualified experts." In fact, the Proposition does not even mention an advisory panel. See generally CaL. HEALTH \& SAFETY CODE $§ \S 25249.5-25249.13$ (West Supp. 1989). 
ment, the Governor needed a decisionmaking group uniquely qualified to make these determinations. ${ }^{36}$ While the working group could have recommended that the Governor simply use experts from the state's public health and environmental protection agencies, ${ }^{37}$ it decided that scientists in academia and private industry would provide the most economical and qualified source of technical advice and information. The Governor accepted the working group's recommendation and formally announced the Panel's creation at a March 1987 press conference. ${ }^{38}$

\section{B. HWA's Regulations Governing the Scientific Advisory Panel}

Pursuant to its authority as lead agency, HWA promulgated regulations governing Proposition 65's implementation. ${ }^{39}$ The regulations incorporate the Governor's designation of the Panel as the state's experts, and include a number of specific provisions relating to the Panel's membership, duties, and decisionmaking procedures. ${ }^{40}$ According to HWA officials, the regulations were designed to ensure that the Panel provides accurate, scientifically based advice and information, while keeping "politics" out of the developinent of the state's list of hazardous substances. ${ }^{41}$

HWA's regulations grant the Governor substantial control over the

36. Telephone interview with Dr. Steven Book, Executive Secretary, Safe Drinking Water and Toxic Enforcement Act Scientific Advisory Panel (Mar. 22, 1989); see also Sacramento Bee, Feb. 28, 1987, at A24, col. 2 (reporting state officials' claims of Panel's ability to carry out its duties under the Act).

37. Indeed, prior to the Panel's creation, both commentators and state officials were contemplating which agencies would assume the role of the "state's qualified experts." See Testimony of Dr. Alexander Kelter, Deputy Director for Public Health (Acting), Department of Health Services, presented before an untranscribed Joint Hearing of the Assembly Environmental Safety and Toxic Materials Committee and the Assembly Water, Parks and Wildlife Committee 2 (Oct. 2, 1986) [hereinafter Testimony of Dr. Kelter] (a copy of Dr. Kelter's prepared statement is on file with the author, and is quoted in NossamAN, GuTHNER, supra note 15, at 80); see also NosSAMAN, GUTHNER, supra note 15, at 104-11 (contemplating the possible roles of various state agencies in the implementation process); San Francisco Chron., Jan. 2, 1987, at 31, col. 3 (predicting designation of California's Department of Health Services as the lead agency).

Instead of designating the Panel as the "state's qualified experts", Governor Deukmejian could have decided to consult experts within the Water Resources Control Board, the Department of Food and Agriculture, or the Department of Health Services (DHS). See San Francisco Chron., Dee. 8, 1986, at 4, col. 2 (suggesting that the Governor might rely on one of these state agencies). In fact, even before voters approved Proposition 65, a high ranking DHS official testified at a state legislative hearing that he expected the Governor to defer to that agency and its GuIDELINES FOR CHEMICAL Carcinogen Risk Assessments and Their Scientific Rationale (1985). See Testimony of Dr. Kelter, supra, at 1-2.

38. See L.A. Times, Mar. 15, 1987, pt. I, at 30, col. 2.

39. CAL. CODE OF REGS. tit. 22, $\S \S 12000-12901$ (1989). Although HWA did not formally adopt its regulations until early 1988, agency officials began drafting preliminary regulations soon after the Panel was created. Various draft regulations are on file with the author.

40. Id. $\$ \S 12301-12305$.

41. L.A. Times, Mar. 15, 1987, pt. I, at 30, col. 2. See generally Statement of Reasons, supra note 8 . 
Panel's membership. The regulations provide for a twelve-member committee comprised of "experts" from six areas of technical specialization relating to the environmental effects of carcinogens and reproductive toxicants: epidemiology, oncology, pathology, reproductive toxicology, teratology, and toxicology. ${ }^{42}$ But within this structure, the Governor has complete discretion both in appointing and removing Panel members: $\mathrm{He}$ is free to appoint any individual regardless of political viewpoint or reputation within the scientific coinmunity; he is not obligated to consult with anyone regarding Panel appointments; ${ }^{43}$ he has the sole power to fill Panel vacancies; and he may remove a Panel member at any time for any reason whatsoever. ${ }^{44}$

HWA's regulations attempt to alleviate potential conflicts of interest on the part of Panel members. ${ }^{45}$ These provisions loosely follow, and often go beyond, other state laws governimg conflicts. ${ }^{46}$ Panel members are required to make annual disclosures of their financial interests in corporations or partnerships that engage in business involving chemicals that "are or may be considered carcinogens or reproductive toxicants."47 Moreover, they must disclose any such investments made at any time during the two years preceding their appointment. ${ }^{48}$ Because many of the Panel's nembers receive private funding for their academic research, those members serving in academic appointments must disclose all sources of funding for significant research projects undertaken both during and within two years prior to their service on the committee. ${ }^{49}$

HWA regulations also govern the Panel's duties as the "state's qualified experts" under Proposition 65, and as a general advisory board to agency officials and the Governor. Although Proposition 65 itself identifies the duties of the state's experts, HWA developed regulations that more fully and clearly describe their duties under the Proposition. For exainple, Proposition 65 states that the Governor must periodically revise the state's list of hazardous substances, ${ }^{50}$ and the regulations require the Panel to meet at least every six months to identify known

42. CAL. CODE OF REGS. tit. 22, § 12302(b) (1989).

43. However, Governor Deukmejian has voluntarily included HWA in the process. ALERT: California Chamber of Commerce, supra note 31 , at 3.

44. CAL. CODE OF REGS. tit. 22, § 12302(b) (1989).

45. Id. § 12304; see also Statement of Reasons, supra note 8, at 36-37.

46. See Political Reform Act of 1974, CAL. Gov'T CODE $\S \S 87202-87203$ (West 1987). It is unclear whether the state's conflict of interest laws would have applied to the Panel's members. In its commentary to the regulations, HWA implies that the Political Reform Act would apply to the Panel. See Statement of Reasons, supra note 8, at 36-37. However, the Pauel's members do not appear to be included in the list of public officials covered by the Act. See CAL. Gov'T CODE $\S 87200$ (West 1987).

47. CAL. CODE OF Regs. tit. 22, § 12304 (1989).

48. Id.

49. Id; see also Statement of Reasons, supra note 8, at 36-37.

50. See supra notes 23-29 and accompanying text. 
carcinogens and reproductive toxicants, and to designate at its discretion other "authoritative bodies" that have identified such cheinicals. ${ }^{51}$ In addition, because Proposition 65 does not specify which "scientifically valid" tests and principles the state's experts should use in designating hazardous substances, the regnlations permit the Panel to establish standards and definitions at its discretion. ${ }^{52}$ Finally, the :":gulations authorize the Panel to identify cheinicals that, upon further testing, may need to be added to the Governor's hist in the future. ${ }^{53}$

Because Proposition 65 requires the Governor to include those substances identified by the state's experts on the list, Proposition 65's plain language suggests that the Panel's identifications of carcinogens and reproductive toxicants have the force of law, and that the Governor must accept thein without question. ${ }^{54}$ Thus, the Scientific Advisory Panel's name may, in fact, be a inisnomer. Unfortunately, the regulations do not exphicitly resolve this issue. ${ }^{55}$ Nevertheless, the Governor has not attempted to reject any of the Panel's identifications, and he appears to have acquiesced to the Panel's apparent authority in identifying substances for listing.

Beyond defining the Panel's duties as the "state's qualified experts," HWA's regulations perinit the Panel to advise the state on a broad range of issues relating to Proposition 65's implementation. Proposition 65

51. Cal. Code of Regs. tit. 22, §§ 12302(c), 12305(a)-(b) (1989). To date, the Panel has identified 267 carcinogens and 17 reproductive toxicants for the Governor to include on the state's list, and has provisionally designated the U.S. Environmental Protection Agency as an authoritative body. See id. $\S 12000 ;$ SAP Passes Provisional Measure Designating EPA as an Authoritative Body, Prop. 65 NEWS, May 1989, at 3.

52. CAL. Code of Regs. tit. 22, § 12305(d)-(e) (1989). The Panel's failure to complete these standards after two years of operations is discussed infra at notes 202-15 and accompanying text.

53. Cal. Health \& Safety Code $§ 25249.8$ (c) (West Supp. 1989).

54. In relevant part, Proposition 65 states that "the Governor shall cause to be published a list of those chemicals known to the state to cause cancer or reproductive toxicity within the meaning of this chapter." Id. $\$ 25249.8$ (a) (emphasis added). The Proposition defines a chemical that is "known to the state to cause cancer or reproductive toxicity within the meaning of this chapter" as one identified by the state's qualified experts. Id. $\$ 25249.8(\mathrm{~b})$. Moreover, the Proposition requires that the Governor "shall identify and consult with the state's qualified experts." Id. $\$ 25249.8(\mathrm{~d})$ (emphasis added).

55. In its explanatory remarks to its regulations, HWA states that "it is intended that the Panel may review, or propose, standards, procedures or protocols for the purpose of advising the lead agency. The Act makes clear that it is within the lead agency's discretion to accept or reject such advice in implementing the Act." Statement of Reasons, supra note 8, at 38. However, the regulations are silent as to the legal effect of the Panel's identifications of hazardous substances.

If the Panel were a federal advisory committee, the answer would be clearer. The Federal Advisory Committee Act, which governs most federal advisory groups, presumes that an advisory committee's role is "advisory only" unless a statute or Presidential directive clearly states otherwise. 5 U.S.C. app. $\$ \S 2(b)(6) \& 9(b)(1988)$. Thus, although federal advisory committees often influence the science policies of agencies they advise, their advice usually does not have the force of law. Federal officials are generally free to accept or reject scientific advisory committee advice at their discretion. 
neither requires nor empowers the Panel to assume this advisory role. Rather, HWA decided that the Panel should provide technical advice and information beyond the identification of hazardous substances, since it would be a "waste of resources not to take advantage of the Panel's collective knowledge."56 As an advisory board, the Panel may review and propose standards, procedures, and statutory definitions both for identifying hazardous substances and for generally facilitating their regulation. ${ }^{57}$ Pursuant to this provision, the Panel has been instrumental in the review of proposed regulations, ${ }^{58}$ and has also set forth its own proposals for carrying out Proposition 65's mandate. ${ }^{59}$ Unlike its identification of hazardous substances, the Panel's advisory findings clearly are not legally binding on HWA officials or the Governor. ${ }^{60}$

Finally, HWA's regulations contam a number of provisions relating to public access and meetimg procedures. ${ }^{61}$ These provisions apply to the Panel's operations both as the state's qualified experts and as an advisory board. As with the conflict of interest provisions, however, many of these requirements may simply modify iminimum standards imposed by other state statutes. ${ }^{62}$ First, im accordance with California's BagleyKeene Open Meeting Act, ${ }^{63}$ the Panel must provide notice of forthcoming meetings, includimg the release of a proposed agenda.$^{64}$ In addition, under the California Public Records Act, ${ }^{65}$ the public may inspect all

56. Statement of Reasons, supra note 8 , at 38 .

57. CAL. CODE OF REGS. tit. 22, § 12305(d)-(e) (1989).

58. For example, HWA requested that the Panel review proposed standards for Proposition 65's "no significant risk" exception to exposure warning reqnirements for known carcinogens set forth in CAL. Health \& SAFETY CoDE $\$ 25249.10$ (c) (West Supp. 1989). See California Health and Welfare Agency, Nature of Emergency Rulemaking: Informative Digest, 22 California Code of Regulations Division 2, Safe Drinking Water and Toxic Enforcement Act of 1986, at 8 (1988) [hereinafter Informative Digest] (on file with author); see also Science Panel Favors FDA Standards for Significant Risk, PROP. 65 NEws, Dec. 1987, at 2. The standards were formally adopted as CAL. Code of Regs. tit. 22, §§ 12701-12721 (1989).

59. See, e.g., Prop. 65 NEWS, June 1989, at 1 (announcing HWA hearing to consider regulations governing discharge limitations and warning requirements).

60. Statement of Reasons, supra note 8, at 38. HWA explains its decision not to permit the Panel's advisory decisions to be binding on the grounds that "[t]he Act makes clear that it is within [HWA's] discretion to accept or reject such advice in implementing the Act." Id. This rationale, however, is suspect in that Proposition 65 is silent as regards the Panel. Moreover, because Proposition 65 says nothing about the state's experts doing anything other than identifying hazardous substances and "authoritative" bodies, it is hard to sec how Proposition 65 "makes clear" HWA's position. See CAL. HeAlth \& SAFETY CODE $§ 25249.8$ (West Supp. 1989).

61. CAL. Code of Regs. tit. 22, § 12302(d)-(e) (1989).

62. See Statement of Reasons, supra note 8, at 35-36 (discussing how HWA's regulations relate to existing California statutory provisions).

63. CAL. Gov'T CoDE $\$ \S 11120-11131$ (West Supp. 1989).

64. CAL. CODE OF REGS. tit. 22, § 12302(d) (1989). Although Bagley-Keene requires only ten days notice, CAL. Gov'T CODE $\$ 11125$ (West Supp. 1989), and the regulations apparently require nothing more, HWA has usually issued public notice about one month in advance of meetings. Statement of Reasons, supra note 8, at 36.

65. CAL. Gov'T CODE $\$ \S 6250-6265$ (West $1980 \&$ Supp. 1989). 
official correspondence to and from the Panel. ${ }^{66}$ All Panel decisions must be approved by a majority of those members voting, and no Panel business inay occur unless six members are present. ${ }^{67}$

\section{The Effectiveness of HWA's Regulations Governing the Panel}

Reaction to the Panel's first two years of operation under HWA's regulations has been mixed. HWA officials contend that the Panel's advice and listing decisions have been scientifically correct and politically impartial, and have engendered sound regulatory policies. ${ }^{68}$ This performance, the officials contend, has been consistent with the spirit of the Proposition's protections against the threats posed by hazardous substances. ${ }^{69}$ In some respects, the regulations appear to have lived up to these claims. Governor Deukmejian has appointed highly trained and hard-workmg scientists to the Panel; the Panel's ten current members have either Ph.D.'s or M.D.'s, and nearly all are associated with major universities or private research institutions. ${ }^{70}$ Many of the Panel's members are renowned leaders in their respective fields, ${ }^{71}$ and a few have served on technical advisory committees for governmental entities such as the Environmental Protection Agency, the Food and Drug Administration, and the World Health Organization. Indeed, while critics have taken issue with some of the committee's decisions and the political views of some of its members, ${ }^{72}$ they have never seriously questioned the pro-

66. CAL. CODE OF REGS. tit. 22, § 12302(d) (1989).

67. Id. $\S 12302(\mathrm{e})$.

68. See Statement of Reasons, supra note 8, at 35 ("Experience with the existing Panel has shown that its decisions whether to list particular chemicals are based upon scientific, not political considerations."); Transcript, Third Mecting of the Safe Drinking Water and Toxic Enforcement Act Scientific Advisory Panel, Aug. 28, 1987, at 6-7 [hereinafter Transcript, 3rd Meeting] (statement of Robert Tousignant, Chief Counsel to the Department of Health Services). Similar ideas havc been voiced by commentators discussing other technical advisory committees. See, e.g., Brooks, supra note 1, at 41-46 ("[S]cientists are often in a position to exercise their political and ethical judgments as citizens in a more realistic and balanced manner than other citizens." Id. at 46); Perl, supra note 2 , at 263 ("This information [provided by science advisory committees] is almost always tcchnically correct and thorough ....").

69. See Statement of Reasons, supra note 8, at 35; see also Kizer, Warriner \& Book, supra note 8 , at 952 .

70. For biographical information on the Panel's members, see Scientific Advisory Panel Named for Proposition 65, Alert: California Chamber of Commerce, Mar. 6, 1987, at 4; see also Transcript, First Meeting of the Safe Drinking Water and Toxic Enforcement Act Scientific Advisory Panel, Mar. 31, 1987, at 1-4 [hereinafter Transcript, 1st Meeting]; Science Advisory Panel Members, Prop. 65 News, Sept. 1987, at 2; Science Advisory Panel Members, Subcommittee on Reproductive Toxicity, Prop. 65 News, Oct. 1987, at 3.

71. For example, Panel member Dr. Bruce Ames has developed one of the most widely used tests for identifying carcinogens, commonly known as the "Ames test." See Nossaman, GUTHNER, supra note 15, at 85 . An in vitro test conducted on cell tissue, the Ames test measures the capacity of a chemical to cause mutations in the bacterium Salmonella typhimurium. See Ames, Identifying Environmental Chemicals Causing Mutations and Cancer, 204 SCIENCE 587 (1979).

72. See infra notes $125-26$ and accompanying text. 
fessional qualifications of any scientist serving on it.

Nevertheless, the Panel has many critics who are not so generous in their evaluations of its performance and the regulations governing its operations. Nearly every group affected by the Panel's decisions, including environmental, labor, consumer, and business interests, has at one time or another accused the Panel of issuing recommendations that are politically rather than scientifically motivated and of engaging in decisionmaking practices that do not reflect sound scientific judgment. ${ }^{73}$ While solne of these criticisms can be dismissed as self-serving, ${ }^{74}$ many appear to have merit. Moreover, some members of the Panel itself have questioned whether its current decisionmaking procedures lead to the best scientific results. ${ }^{75}$

Most disturbing, though, are the recent resiguations of two Panel members amid charges they had excessive ties with industries affected by the Panel's decisions. ${ }^{76}$ One of the members has also been under investigation by the Environmental Protection Agency for possible ethics violations stemming from his testifying on behalf of a trade association representing pesticide users. ${ }^{77}$ Although no specific accusations have been made regarding the two meinbers' service on the Panel, the incident has tainted the Panel's reputation.

Unfortunately, the Panel's relatively short period of existence makes it difficult to assess critically the Panel and the regulations under which it operates. Nevertheless, it is already clear that the regulations fail to

73. See Carrick, Free the Science Advisory Panel 12, Prop. 65 NEws, Sept. 1987, at 7 (criticizing many of HWA's restrictions on Panel decisionmaking); L.A. Times, June 30, 1989, pt. I, at 29, col. 3 (accusing the Panel of having a "pro-industry" bias); L.A. Times, Apr. 23, 1988, pt. I, at 1 , col. 5 (industry representatives protesting the lack of conclusive scientific studies proving alcoholic beverages are carcinogenic); L.A. Times, Jan. 30, 1988, pt. I, at 30, col. 1 (industry representatives criticizing the Panel's decision to recommend listing tobacco smoke and smokeless tobacco as known carcinogens); Meyerhoff, supra note 9 (criticizing industry influence on Panel decisions); L.A. Times, Dec. 12, 1987, pt. I, at 26, col. 1 (environmental interest criticism of the Panel's list of carcinogens); Sacramento Bee, Dec. 12, 1987, at A1, col. 4 (same); L.A. Times, Aug. 29, 1987, pt. I, at 1, col. 1 (consumer interests seeking more restrictive labeling than Panel recommendations); L.A. Times, Feb. 28, 1987, pt. I, at 1, col. 2 (labor interests criticizing the definition of "carcinogens" as limited to agents causing cancer in humans).

74. For example, the Panel has yet to consider a chemical for listing without recommending that it be classified as either a known carcinogen or a reproductive toxin. Surely by no coincidence, environmental, labor, and consumer groups have rarely criticized the Panel's listing decisions, although they often have criticized other aspects of its decisionmaking. Criticism by industry representatives of the Panel's listing decisions, however, has been frequent and fierce. See, e.g., L.A. Times, Apr. 23, 1988, pt. I, at 1, col. 5 (industry representatives criticizing the Panel's decision to recommend listing alcohol as a known carcinogen); L.A. Times, Jan. 30, 1988, pt. I, at 30, col. 1 (similar criticism of the Panel's recommended listing of tobacco smoke and smokeless tobacco products as known carcinogens); L.A. Times, Aug. 29, 1987, pt. I, at 1, col. 1 (similar criticism of the Panel's rccommended listing of alcohol as a known reproductive toxin).

75. Telephone interview with Dr. Brenda Eskenazi, Panel member (Mar. 29, 1989).

76. L.A. Times, June 30,1989 , pt. I, at 29 , col. 3.

77. Id. 
address a number of systemic defects in the Panel's operations. In particular, they fail to ensure that the Panel has a balanced membership, that its decisionmaking is unaffected by improper political influences, and that its decisionmaking procedures properly account for the presence of scientific uncertainty.

The following discussion considers whether HWA's regulations have facilitated good scientific decisionmaking, ${ }^{78}$ and, inore importantly, whether the Panel's decisions have resulted in good regulatory policies. Where the Panel has accomplished its objectives to date, the following Parts also consider whether it will continue to do so in the future, and they propose changes to improve the Panel's role in the Proposition 65 miplementation process. First, however, Part II examines a critically flawed assumption underlying HWA's regulations, a flaw that has led directly to inany of the Panel's current problems and threatens to cause additional probleins in the future.

II

\section{THE ERRONEOUS ASSUMPTION UNDERLYING HWA'S CURRENT REgULATIONS}

HWA's regulations reflect the same widely held, yet flawed, assumption that underlay the Panel's creation and the Governor's subsequent designation of it as the "state's qualified experts." State officials assumed that the Panel could base its technical advice and identifications of hazardous substances solely on objective scientific facts. Accordingly, they believed that the Panel could avoid consideration of nonscientific issues, therefore insulating its decisionmaking processes from the negative effects of pohitical bias. ${ }^{79}$ Thus when Governor Deukmejian first offcially designated the Panel as the state's experts at a March 1987 press conference, he emphasized the desirability of keeping politics out of Proposition 65's implementation and the unique ability of the Panel to carry out this goal: "What we are doing is turning this decision over to the scientists, to the experts. ... It won't be politicians making the decision. It won't be lobbyists for the business interest or lobbyists for environmental interests." $\$$

78. Because the identification of carcinogens and reproductive toxins often hinges on scientific uncertainties, perhaps this question is better phrased as whether the Panel has avoided making clearly inaccurate scientific determinations during its first eighteen months. For a further discussion of scientific uncertainty and the Panel's decisionmaking, see infra notes 98-102 and accompanying text.

79. Even the Proposition's backers claimed that much of its implementation could be based strictly on scientific data. See Reiner, Torres \& Newman, Argument in Favor of Proposition 65, in California Ballot Pamphlet, General Election, Nov. 4, 1986, at 54 [hereinafter California Ballot Pamphlet].

80. L.A. Times, Mar. 15, 1987, pt. I, at 30, col. 2. For purposes of this discussion, it is 
HWA shared the Governor's faith in the Panel's ability to remove politics from the implementation process and justified a number of its regulatory provisions governing the Panel's membership and operations on the grounds that its decisions would be purely scientific. For example, the Agency rationalized its grant to the Governor of almost complete discretion over the appointment and removal of Panel members with a claim that the positions were nonpolitical. ${ }^{81}$ According to HWA, limits on the Governor's discretion were not necessary when dealing with "scientists who are making judgments on matters of science."82

The Panel's operations during its first two years, however, liave shown tlis fundamental assumption to be wrong. The Panel has routinely addressed issues for whicli there exist no definitive scientific resolutions. Moreover, the Panel has often addressed issues that are inherently political and, therefore, can never be answered by science. When confronting these situations, the Panel's members have often resorted to nonscientific value judgments to resolve the issues before them. This Part examines the flawed assuinption under which HWA promulgated its regulations. The Parts that follow consider what impact this incorrect assumption has had or may have on the Panel's operations.

\section{A. Regulatory Decisionmaking in the Face of Scientific Uncertainty}

The Governor's and HWA's assumption that a panel of expert advisors could be assembled to consider only questions of science has ample precedent within the scientific and legal communities. A number of commentators have proposed decisionmaking models based on the theory that the scientific aspects of governmental policy decisions can be separated and addressed independently from their nonscientific aspects. Advocates of this theory, sometimes referred to as "Scientific Separatism," 83 beheve that scientists advising government officials can iguore the political, social, and economic significance of governmental policies, ${ }^{84}$ and can provide government witl objectively "correct" information based solely on science, which lay officials can then use in

unnecessary to speculate whether the Governor and HWA officials really believed that these decisions were purely scientific; it is sufficient that they have publicly used this assertion to justify many of their regulations.

81. See Statement of Reasons, supra note 8, at 35 (responding to several commentators' concerns regarding the political aspects of Panel appointments); see also Transcript, 3rd Meeting, supra note 68, at 6-12 (stressing the scientific basis of Panel decisions); Sacramento Bee, Feb. 28, 1987, at Al, col. 3 (same).

82. Statement of Reasons, supra note 8, at 35 .

83. See Carter, Separatism and Skepticism, 92 YALE L.J. 1334 (1983).

84. The theoretical operation of the Separatist model is best illustrated through an example. During the early 1970s, the United States government debated the merits of the development of the supersonic transport (SST). The SST debate centered around a number of complex environmental issues, such as noise and potential destruction of the ozone layer due to high level atmospheric 
formulating public policy. ${ }^{85}$ The rationale underlying this theory is twofold: that purely objective scientific advice can lead to more rational science policies, and that politically accountable government officials, rather than independent scientists, should decide nonscientific policy issues. ${ }^{86}$

Attempts to achieve Scientific Separatism have inspired much legal commentary and, to a significantly lesser extent, actual governmental practice. ${ }^{87}$ The most ambitious of these efforts is the ill-fated "science court" proposal. The science court's remaining proponents contend that, if established, the court would resolve technical regulatory issues in a purely scientific forum, ${ }^{88}$ determining scientific facts in an adversarial manner similar to that used by law courts to determine the facts in a

emissions, as well as a number of political issues, such as price and the plane's national defense ramifications.

While the critical issue in the SST debate was whether its environmental risks were socially and politically acceptable when weighed against nonscientific considerations, the Separatist model suggests that government decisionmakers first should have determined the environmental risks based on the best scientific data available, without any reference to the non-scientific issues. Only after these purely scientific determinations were made should they have addressed the question of whether the risks were actually justified in light of the potential benefits offered. Thus, government officials should have carried out a two-part inquiry: science first and policy second. See J. PrImaCk \& F. von Hippel, AdVice and Dissent: Scientists in the Political AReNa $49-58$ (1974); Clark, Expert Advice in the Controversy About the Supersonic Transport in the United States, 12 MinERVA 416 (1974); Perl, supra note 2, at 268.

85. The difficult question of whether science can achieve results with absolute certainty is beyond the scope of this discussion, although it has been addressed by a number of scholars. See T. Kuhn, The Structure of Scientific Revolutions (1970); McGarity, Substantive and Procedural Discretion in Administrative Resolution of Science Policy Questions: Regulating Carcinogens in EPA and OSHA, 67 GEo. L.J. 729, 747-49 (1979); see also Ethyl Corp. v. EPA, 541 F.2d 1, 25 n.52 (D.C. Cir.), cert. denied, 426 U.S. 941 (1976) ("Even scientific 'facts' are not certain, but only theories with high probabilities of validity. . . . The uncertainty of scientific facts parallcls the uncertainty of all fact. In a metaphysical sense, at least, facts are themselves nothing more than risks, or statistical probabilities.").

86. The argument that scientific and non-scientific questions can and should be addressed independently is well entrenched in a number of current models of technical decisionmaking. See, e.g., Latin, Good Science, Bad Regulation, and Toxic Risk Assessment, 5 Y ALE J. ON REg. 89, 95-105 (1988) (criticizing the scientific decisions of the EPA's carcinogen guidelines); McGarity, supra note 85 , at 742-43 ("The most effective way for a lay decisionmaker to avail himself of scientific judgment, while at the same time filtering out scientists' public policy judgments, is to ask the scientists precise questions. The decisionmaker should narrowly limit his questions to those issues requiring scientific expertise, and should not demand that the scientists exercise policy judgment." (footnote omitted)).

87. See Latin, supra note 86 , at 95 (noting that the belief that scientific decisions can be separated from nonscientific policy considerations "is becoming entrenched in a myriad of regulatory programs as agencies increasingly rely on quantitative risk assessment, risk-benefit analysis, or cost-benefit analysis to justify pollution control decisions and to establish staff priorities" (footnotes omitted)); Yellin, Science, Technology, and Administrative Government: Institutional Designs for Environmental Decisionmaking, 92 YALE L.J. 1300, 1308-16 (1983) (discussing the futility of attempts to separate science and policy).

88. See Kantrowitz, Controlling Technology Democratically, 63 AM. ScIENTIST 505 (1975) (positing Scientific Separatism as a valid assumption upon which to base a science court); Martin, supra note 1, at 1059 (favoring the separation of science from policy within a science court); Notc, supra note 1 , at $447-49$ (same). 
legal case or controversy. Instead of nonscientist judges and jurors, however, the trier of fact would consist of trained scientists who, in theory, could evaluate technical issues on a purely objective, scientific basis. The science court would forward its findings to government officials who would afford the court's scientific findings great weight in inaking policy decisions. ${ }^{89}$

Although the science court proposal has never been adopted in full, a few governmental entities (in addition to HWA) have attempted to implement the idea of Scientific Separatism on a more limited scale. For example, scientists who assess the carcmogemic dangers of chemicals for the EPA must make their risk assessments "independently from considerations of the consequences of regulatory action."90 EPA scientists may "use [only] the most scientifically appropriate interpretation" of data to assess risk: ${ }^{91}$ The balancing of policy considerations against the scientific evidence is reserved solely for the EPA officials for whom the risk assessments are performed. ${ }^{92}$

The science court proposal and other attempts at Scientific Separatism are inherently flawed because they fail to recognize the limits of pure science in solving regnlatory problems; ${ }^{93}$ it is usually mipossible for decisionmakers to consider the scientific and nonscientific aspects of a particular regulatory problem independently. ${ }^{94}$ The line between science and values is often blurred, and nearly every technical regulatory decision is based im part on underlying value judgments that cannot be evaluated empirically. ${ }^{95}$ Separatism, therefore, is probably little more than a

89. Note, supra note 1 , at $447-48,506-07$ (under the science court proposal, scientists would be responsible for determining scientific facts, which decisionmakers would give great weight in the resolution of policy disputes).

90. EPA Guidelines for Carcinogen Risk Assessment, 51 Fed. Reg. 33,992, 33,993 (1986). For criticism of this EPA policy, see Latin, supra note 86.

91. 51 Fed. Reg. 33,992 (1986).

92. The EPA classifies the nonscientific aspects of regulating carcinogenic hazards as "risk management," rather than "risk assessment." Id. at 33,993; see also Ruckelshaus, Science, Risk, and Public Policy, 221 ScIENCE 1026 (1983) (distinguishing between "risk assessment," which is the objective, scientific determination of a substance's toxicity, and "risk management," which is the policy determination involved in setting the socially optimum level of permissible risk).

93. See Korn, Law, Fact, and Science in the Courts, 66 CoLUM. L. REv. 1080, 1090-91 (1966) (contending that scientific facts are not completely responsive to legal questions containing nonscientific policy implications); Latin, supra note 86, at 95-105 (criticizing the EPA's separation of scientific risk assessments and policy-based risk management); Yellin, supra note 87, at 1308-16.

94. See Committee on the Institutional Means for Assessment of Risks to Public

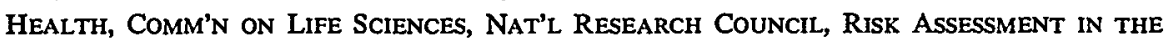
Federal Government: Managing the Process 48 (1983) ("Risk assessment . . . requires judgments to be made when the available information is incomplete. These judgments incvitably draw on both scientific and policy considerations." (emphasis omitted)); Latin, supra note 86, at 94; Yellin, supra note 87 , at $1308-16$.

95. For other discussions recognizing the blurring of science and policy, see Ashford, Advisory Committees in OSHA and EPA, supra note 2, at 74; McGarity, supra note 85, at 732-36; Curbing Ignorance and Arrogance: The Science Court Proposal and Alternatives, 19 JURIMETRICs J. 387, 421 
theoretical concept which has almost no application in real life regulatory decisionmaking.

Because purely scientific decisionmaking rarely exists, scientists who advise government officials usually address mixed issues of science and values, often referred to as "trans-scientific" questions. ${ }^{96}$ Introduced by scientist Alvin Weinberg, trans-science refers to those issues that "arise in the course of the interaction between science or technology and society ... and yet which cannot be answered by science."97 Although science plays a significant role in the resolution of trans-scientific regulatory issues, it must share that role with nonscientific policy considerations.

\section{B. The Panel and Trans-Scientific Decisionmaking}

Notwithstanding the clains of the Governor and HWA officials that the Panel would consider only purely scientific issues, most of its advisory findings and listing decisions have been trans-scientific. ${ }^{98}$ For example, as the state's qualified experts, the Panel must identify carcinogens and reproductive toxicants based on "scientifically valid testing" and "accepted [scientific] principles." such principles or testing methods, because to do so depends on the resolution of questions outside the limits of current scientific knowledge. ${ }^{100}$ To resolve these uncertainties, scientists must turn to something other than proven scientific facts.

Consider, for example, the problems the Panel has encountered in using data from research involving the use of laboratory animals to iden-

(1979) (statement of Professor Dorothy Nelkin) ("The belief that science is inherently removed from political consideration and that scientists are, therefore, political celibates is a longstanding one, but in the present social context of science, it is an anachronism."). But see Clark, supra note 84, at 419. 30 (contending that a division of science and policy could be maintained in the context of the SST debate).

96. See, e.g., Majone, Science and Trans-Science in Standard Setting, 9 Scr. TECH. \& HuM. VAlues 15, 15 (1984); McGarity, supra note 85, at 733; Weinberg, Science and Trans-Science, 10 MiNERVA 209, 209 (1972).

97. Weinberg, supra note 96, at 209 (emphasis omitted); cf. Majone, supra note 96, at 15 ("Trans-scientific questions ... are questions that can be stated in the language of science but are, in principle or in practice, unanswerable in purely scientific terms.").

98. One cannot blame only the Governor and HWA officials for advancing the myth that the Act could be implemented solely based on scientific principles. The Act's own supporters made similar claims during the Proposition 65 campaign, probably because they believed that "science" carries with it a notion of legitimacy and public acceptance that the political process lacks. See, e.g., Reiner, Torres \& Newman, supra note 79, at 54 ("Proposition 65 singles out chemicals that are scientifically known to cause cancer or reproductive disorders . ..."); Upton, Freestone \& Gerston, Rebuttal to Argument Against Proposition 65, in CALIFORNIA BALLOT PAMPHLET, supra note 79, at 55 ("Proposition 65 is based strictly on scientific testing, more than any existing toxics law.").

99. Cal. Health \& SAfety Code § 25249.8(b) (West Supp. 1989).

100. See generally McGarity, supra note 85 , at $736-40$ (discussing decisionmaking in the face of insufficient scientific data); id. at 740-47 (discussing disagreements among scientists over the proper inferences to be drawn from existing data). 
tify suspected human carcinogens and reproductive toxicants. While most scientists believe that these studies are often reliable, the scientific community does not fully understand the relationship between data from aninial experimentation and the actual effects of exposure on humans. ${ }^{101}$ As a result, when Panel members use data from animal experimentation in evaluating a substance for listing, they cannot reach a conclusion based solely on scientific fact. Although the Panel's members may search for scientific "certainty," they inevitably must make decisions based on little inore than "educated guesses." 102

Scientific uncertainties create a rift between the desire to follow accepted scientific practices and the needs of regulatory decisioninaking. ${ }^{103}$ Science emphasizes careful, deliberate research in which conclusions are not reached until theories are tested and retested. Regulatory decisionmaking, on the other hand, typically requires quick action in response to pressing social problenis, such as those created by the threat of hazardous substances. ${ }^{104}$ Regulators often inust act before a particular issue is fully understood by the scientific community because to delay will often only exacerbate the problem. ${ }^{105}$ Thus, when independent scientists are brought into the regulatory process, they often nuust reach decisions as advisors before they would be willing to do so as scientists. The inevitable gaps in their scientific knowledge inust then be filled by nonscientific policy judgments. Even definitions of seeningly scientific terms such as "carcinogenicity" and "reproductive toxicity" hinge on nonscientific considerations of what society is willing to accept as a de mininis risk of harm from hazardous substances. Yet, the Panel has been called upon to define terms such as these, and to resolve other issues that depend as nuch upon policy as science.

Consider, for exanple, the Panel's review of a HWA-proposed stan-

101. Id. at 743-46.

102. Cf. Ashford, Advisory Committees in OSHA and EPA, supra note 2, at 73 (arguing that science panels are competent to make policy recommendations based on best estimates of risk when a purely scientific, factual determination is not possible).

103. The tension between the need for regulatory action and the desire to maintain "good" scientific practices is widely discussed in the literature on technical regulatory policies. See Latin, supra note 86, at 92-93; McGarity, supra note 85, at 736-38; Yellin, supra note 87, at 1309-16 (even in the absence of complete scientific data, scientific panels have a duty to act to protect the public based on the best information available); Note, The EPA and Biotechnology Regulation: Coping with Scientific Uncertainty, 95 YALE L.J. 553, 560-63 (1986) (authored by Ruth E. Harlow) (contending that the value judgments of individual committee members intrude upon the risk assessment process).

104. McGarity, supra note 85 , at $736-37$.

105. See Latin, supra note 86 , at 126 ("[R]egulators must decide how much potential but uncertain public protection should be traded for some potential but uncertain inprovenent in the accuracy of scientific judgments."); McGarity, supra note 85, at 734 ("Regulators cannot . . . postpone decisions involving trans-scientific issues while awaiting definitive data from the scientific cominunity."); Note, supra note 103, at 562 ("The decisionmaker cannot refrain from action indefinitely" as "hoping for scientific certainty . . . would disserve society."). 
dard defining the term "significant risk."106 Proposition 65 requires that a "clear and reasonable" warning accompany goods and services that expose the public to known carcinogens, but exempts items that pose "no significant risk assuming lifetime exposure at the level in question."107 Pursuant to the Panel's advisory role, HWA asked it to render an opinion on the proposed standard. After lengthy deliberation, the Panel recommended that HWA define the no-significant-risk level for concentrations of hazardous substances in foods, drugs, cosmetics, and medical devices in accordance with preexisting state and federal regulations. ${ }^{108}$ Although the Panel reserved the right to reconsider warning requirements for individual substances based on subsequent risk assessments, ${ }^{109}$ its recommendation (as adopted by HWA) effectively exempts as many as 15,000 common products from the Act's warming requirements. ${ }^{110}$

Regardless of its wisdom, the Panel's decision on the significant risk issue clearly illustrates the trans-scientific nature of its functions. "Significant risk" is a trans-scientific term because, in nearly every context, "significance" is not a purely scientific concept." "In determining an acceptable level of exposure to a hazardous substance, significance must be measured both in terms of the causal relationship between exposure to the substance and incidence of cancer, a scientific fact, and by the social acceptability of permitting that relationship to go unregnlated.

Not surprisingly, the Panel had to consider both scientific and nonscientific questions $m$ deciding the significant risk issue, in spite of HWA's requests that it base its decision primarily on science. ${ }^{112}$ Throughout the Panel's fifth meeting, its members responded to com-

106. See Informative Digest, supra note 58 , at $8 ; H \& W$ Asks $S A P$ to Consider Feasibility of Existing Standards for Determining Significant Risk, PROP. 65 NEws, Nov. 1987, at 1 [hereinafter $H$ \& W Asks SAP].

107. Cal. Health \& SAFETY CODE $\$ \S 25249.6,25249.10$ (c) (West Supp. 1989). In rather convoluted language, the relevant section provides that Proposition 65's "clear and reasonable warning" requirement does not apply to

[a]n exposure for which the person responsible can show that the exposure poses no significant risk assuming lifetime exposure at the level in question for substances known to the state to cause cancer . . . based on evidence and standards of comparable seientific validity to the evidence and standards which form the scientific basis for the listing of such chemical pursuant to [California Hcalth \& Safety Code section 25249.8(a)].

Id. $\S 25249.10(\mathrm{c})$.

108. Transcript; fifth Meeting of the Safe Drinking Water and Toxic Enforcement Act Scientific Advisory Panel, Dec. 11, 1987, at 179-80 [hereinafter Transcript, 5th Meeting]. The Panel's recommendation has since been codified as CAL. CODE of REGS. tit. 22, $\$ 12701-12713$ (1989).

109. Transcript, 5th Meeting, supra note 108 , at 179-80.

110. See $H \& W$ Asks SAP, supra note 106 , at 1 .

111. Although scientists often employ the term "significance" to describe the de minimis statistical level at which data will be considered important or relevant, they do so typically because of nonscientific factors such as inadequate instrumentation, budgetary limitations, or time constraints. Thus, "significance" is often more an indication of the uncertainty of current scientific knowledge, rather than an empirical fact. See McGarity, supra note 85, at 740-43.

112. See SAP Considers Significant Risk Issue, ProP. 65 NEwS, Dec. 1987, at 3 (request by 
ments by mdustry and environmental spokespersons who emphasized policy considerations as well as scientific factors. ${ }^{113}$ Consequently, much of the Panel's discussion addressed concerns such as public confidence in existing labeling policies and diluting the significance of labeling by requiring relatively safe products to carry warnings. In order to set a significant risk standard, the Panel had to transcend a consideration of objective scientific facts and examine nonscientific policy issues.

That the Panel makes trans-scientific policy decisions is not necessarily bad. Although inany scientists may be no inore coinpetent than lay persons on nonscientific issues of public policy, most are probably no less coinpetent, either. Generally, scientists should be able to understand the basic nonscientific policy considerations underlying the regulation of hazardous substances, ${ }^{114}$ and many of the Panel's decisions, particularly those relating to listing, still have significant technical aspects that are beyond the comprehension of lay officials. Finally, elected officials review inany of the Panel's nonscientific recoinmendations; although the Panel inakes apparently binding listing decisions for individual chemicals, it can only recoinmend implementation policies. ${ }^{115}$

HWA's guidelines are nevertheless inadequate. They were not designed to govern scientists engaging in both scientific and nonscientific inquiries. Because the Panel must inevitably address policy issues, the political opinions of its members-even the most esteemed scientists often are as politically opinionated as lay persons ${ }^{116}$ - will undoubtedly influence the advice it provides policymakers. And because complex technical issues are involved, it is often impossible for lay persons to know what effect political considerations have had on their scientific advisors.

In addition, it should be noted that many of the Panel's decisions to date, particularly its recominendations for listing known carcinogens and reproductive toxins, have been relatively easy. So far, the Panel has only considered substances that other scientific bodies have identified as known or suspected environmental hazards. ${ }^{117}$ The Panel, however, has

HWA Deputy Secretary that the Panel make sure that "science plays a significant role" in its decision).

113. See, e.g., Transcript, 5th Meeting, supra note 108, at 168-71 (statement of David Roe, senior attorney for the Environmental Defense Fund).

114. Indeed, at least one commentator has noted that science advisory committees are a convenient method to bring the most intelligent and well-educated individuals into governmental decisionmaking, whether for technical or nontechnical advice. Brooks, supra note 1, at 44-45.

115. See supra note 60 and accompanying text.

116. See McGarity, supra note 85 , at 742 .

117. See Transcript, 1st Meeting, supra note 70, at 6-7 (HWA asks Panel to consider listing 201 substances found hazardous by other authoritative bodies); see also id. at 13-44 (reviewing IARC's and NTP's methodologies for evaluating hazardous substances).

Although the first 201 substances considered for listing had been identified by IARC, NTP, and 
recently begun to consider substances for which the evidence of carcinogenicity and reproductive toxicity is less certain. ${ }^{118}$ Thus, trans-scientific issues undoubtedly will play an increasingly greater role in the Panel's future decisions, and it is critical that HWA amend its regulations to address adequately the problem of regulatory decisionmaking in the face of scientific uncertainty. The following Parts examine how trans-science has affected the Panel's operation under HWA's current regulations, and propose amendments to enable the Panel to perform better as it addresses problems for which there are no certain answers.

III

HWA's Provisions Governing Panel Membership

\section{A. The Consequences of Trans-Science on Panel Membership}

During the notice and comment period for HWA's regulations, a number of commentators advocated limiting the Governor's discretion in appointing and removing Panel members by, for example, requiring "good cause" to remove Panel members or establishing fixed-membership terms. HWA officials rejected these proposals, however, contending that because the Panel was a scientific and not a political body, such restraints would unnecessarily inhibit the Governor's flexibility in identifying the state's qualified experts, without providing any real benefits. ${ }^{119}$ HWA found "no reason to believe that the [Panel's scientific] determinations would be any different if there were a change in [its] membership." 120

Because HWA officials failed to recognize the trans-scientific nature of the Panel's decisionmaking, they could not appreciate the impact the Governor could have on its decisions. Since the resolution of trans-scientific issues depends upon the decisionmaker's subjective values and opin-

OSHA as suspected carcinogens, they were not included on the Governor's initial list in accordance with $\S 25249.8(a)$. CAL. Health \& SAFETY Code $\S 25249.8(a)$ (West Supp. 1989). The Governor believed that the initial list need only include those substances identified by IARC and NTP as "known" human carcinogens or reproductive toxicants, not merely as "suspected" toxins. A California Court of Appeal has recently held that the Governor had incorrectly excluded the "suspected" human carcinogens from the list, and ordered him to add them retroactively. See AFLCIO y. Deukmejian, 212 Cal. App. 3d 425, 440-41, 260 Cal. Rptr. 479, 487 (1989); see also supra note 26.

118. For example, the Panel began its process of identifying carcinogens by examining those substances previously classified by the EPA as either "human carcinogens" or "probable human carcinogens," both of which require a fairly high degree of evidence from epidemiological or laboratory animal studies linking the substance to incidents of cancer. See EPA Guidelines for Carcinogen Risk Assessment, 51 Fed. Reg. 33,992, 34,000 (1986). The Panel has recently completed evaluating these substances and is now beginning to consider substances classified by the EPA as merely "possible human carcinogens," for which there is relatively little data linking the substance to incidents of cancer. See id.

119. Statement of Reasons, supra note 8, at 35.

120. Id. 
ions as much as upon empirical facts, the identity of the decisionmaker necessarily affects the decision reached. As a result, the Governor can use his unbridled discretion over the Panel's membership to influence ultimate decisions by appointing scientists who share his political viewpoints and removing those who do not.

The Governor has a strong incentive to "stack" the Panel with those who share his views. Scientists enjoy a high level of prestige in society, and their opinions are often met with more public acceptance than those of politicians. ${ }^{121}$ Realizing this, government officials often use advisory committees to forward their own pohtical agendas under the guise of recommendations from "imdependent" decisionmaking bodies. ${ }^{122}$ By creating stacked committees, government officials can claim that an otherwise dubious or unpopular policy has the endorsement of the scientific commumity, and at least a veneer of scientific legitimacy.

It remains unclear, however, whether Governor Deukmejian has actually stacked the Panel to promote his own political outlook. Although the Panel's membership generally reflects the Governor's view of toxics regulation, its decisions have not always done so. For example, in identifying carcinogens and reproductive toxicants the Panel has consistently reached decisions contrary to business interests allied with the Governor. Those decisions have often been made over the strong objections of industry spokespersons, mcluding those of the powerful tobacco and alcoholic beverages lobbies. ${ }^{123}$ Thus, there appears to be some merit to HWA's contention that "[e]xperience with the existing Panel has shown that its decisions whether to list particular chemicals are based upon scientific, not political considerations." 124

Nevertheless, critics still contend that Governor Deukmejian's appointments to the Panel mirror his own political views. To support their claim, critics point out that the Governor appointed only two of the forty scientists recommended by environmental and consumer interests for Panel membership. ${ }^{125}$ Moreover, the Panel's critics were particularly upset by the Governor's appointment of Dr. Bruce Ames, a prominent biologist who strongly opposed Proposition 65 and other efforts to regu-

121. Perl, supra note 2, at 270 .

122. T. Wolanin, Presidential Advisory Commissions 15-20 (1975) (discussing the use of advisory committees as "window dressing" for predetermined policies); Perl, supra note 2, at 270; see also J. Primack \& F. VON HIPPEL, supra note 84, at 38-100 (giving examples of specific political abuses of the advisory committee system); Ashford, Advisory Committees in OSHA and EPA, supra note 2, at 76-79; Brooks, supra note 1, at 44; Gage \& Epstein, supra note 2, at 50,004-05 (discussing "balanced representation" under the Federal Advisory Committee Act).

123. See, e.g., San Francisco Chron., Apr. 23, 1988, at 1, col. 1; L.A. Times, Jan. 30, 1988, pt. I, at 30 , col. 1 .

124. Statement of Reasons, supra note 8 , at 35 .

125. L.A. Times, Mar. 15, 1987, pt. I, at 30, col. 5; Sacramento Bee, Feb. 28, 1987, at A24, col. 3. 
late hazardous substances. ${ }^{126}$ Many critics thus believe that, rather than appointing an independent group of experts, the Governor used his appointınent power to ensure that the iinplementation process remain within the pohtical control of his administration.

In any event, even if Governor Deukmejian has not yet used his appointınent and reinoval authority to stack the Panel, some critics fear that he or soine future governor inay yet attempt to do so. ${ }^{127}$ Although we have not had an opportunity to see how a change in administration will affect the Panel's inembership, it seeins likely that former Governor Jerry Brown would have had a different vision of an ideologically correct Panel than Governor Deukmejian, and that Governor Brown's vision would in turn have differed from that of his predecessor, Ronald Reagan. Undoubtedly, their appointments to the Panel would have reflected their differences in ideology. And, as the Panel begins to consider substances for which the scientific evidence is less certain, ${ }^{128}$ the risk of stacking increases.

\section{B. Providing the Panel With a Balanced Membership}

In order to ensure a fair balance of viewpoints on the Panel, HWA should adopt regulations that permit interested persons greater participation in the selection of the Panel's inembers. HWA can adopt such provisions, however, only if Proposition 65 itself does not grant the Governor plenary authority over Panel appointınents. Although the law is unclear on this point, it appears that HWA can inpose at least some additional restrictions on the Governor's authority.

Proposition 65 provides that the Governor inust "identify and con-

126. Dr. Ames has repeatedly questioned the need to regulate synthetic carcinogens because, in his opinion, natural carcinogens pose far greater health risks than do manmade ones. See Transcript, 3rd Meeting, supra note 68, at 24 ("[O]ver 99 percent of the chemicals we are eating are natural, not manmade; and the world is full of natural carcinogens."); Ames, Voss \& Ottoboni, Argument Against Proposition 65, in CAL1Fornia Ballot PAMPHLET, supra note 79, at 55 ("The simple scientific fact of the matter is that manmade carcinogens represent only a tiny fraction of the total carcinogens we are exposed to, most of which are natural substances such as tobacco, alcohol, and chemicals in green plants."). While his opinion may in fact be correct, his conclusion that many manmade carcinogens should not be heavily regulated is not shared by environmentalists and consumer advocates. See San Francisco Chron., Feb 27, 1987, at 28, col. 1; see also Transcript, 3rd Meeting, supra note 68, at 52 (testimony of Dr. Kim Hooper, Department of Health Serviees, challenging Dr. Ames' assumption that a significant number of carcinogens are naturally produced).

127. See Statement of Reasons, supra note 8, at 35 (responding to concerns that changes in administration would lead to changes in Panel membership). According to HWA, it is not correet to assume that "changes in the political climate will infiuence the manner in which advice is provided to the Governor." Id. In this context, "'manner" refers to the Panel's membership, not to the way that the Panel actually reaches its conclusions. Nevertheless, because the Panel engages in political decisionmaking, it is unlikely that subsequent adıninistrations would not exercisc their removal and appointment powers to alter the Panel's membership to reflect their own views.

128. See supra notes $117-18$ and accompanying text. 
sult" with the state's qualified experts. ${ }^{129}$ But, as noted previously, it is silent as to the Panel's existence, and it offers no guidance as to who should constitute the state's experts. ${ }^{130}$ Nor does it discuss HWA's role in the selection process as the Proposition's "lead agency." Although one inight infer from the Proposition's silence that the Governor has the ultimate authority for determining which organizations or individuals constitute the state's experts, ${ }^{131}$ experience during the Panel's first two years of operation indicates otherwise.

At no time during these two years has any state official interpreted Proposition 65 as granting the Governor absolute authority over Panel inembership. Neither the Governor nor any HWA official has ever questioned the vahidity of HWA's regulatory provisions governing the Panel's membership, albeit these restrictions on his discretion are minimal. ${ }^{132}$ Instead, the Governor has appointed experts only froin the six required areas of specialization, and has selected a panel chairperson and executive secretary in accordance with the regulations.

In addition, even though the Agency generally has been careful to discuss how its proposed regulations would interact with other state laws, ${ }^{133}$ neither it nor any person commenting on the regulations identified a potential conflict between the proposed Panel membership provisions and Proposition 65. In fact, a number of private mdividuals suggested that HWA adopt stricter himitations on the Governor's discretion. ${ }^{134}$ While HWA ultimately rejected these proposals, it did so because it believed that the limitations were unnecessary, not because it believed that they were not allowed. ${ }^{135}$ Consequently, although HWA's regulations essentially do so at present, Proposition 65 itself probably does not grant the Governor complete discretion over the Panel's membership.

Pursuant to its authority as the "lead agency," HWA should impose

129. CAL. Health \& SAfety CODE $\S 25249.8$ (d) (West Supp. 1989).

130. See supra note 35 and accompanying text.

131. See ANAlysis of Proposition 65, supra note 16, at $19-20$ (discussing how the Governor's power over selecting the state's qualified experts "will profoundly effect the implementation of" Proposition 65); Nossaman, GUTHNER, supra note 15, at 78-80 (discussing how the governor may select the "state's qualified experts" and determine which chemicals belong on the list).

132. See supra notes $42-44$ and accompanying text.

133. See, e.g. Statement of Reasons, supra note 8, at 36 (discussing relationship between the regulations' open meeting requirements and California's Bagley-Keene Open Meeting Act); id. (discussing relationship between the regulations' open records requirements and California's Public Records Act); id. at 36-37 (discussing relationship between the regulations' conflict of interest provisions and the California Government Code).

134. See id. at 35 .

135. Indeed, HWA has indicated that it might consider imposing limits on the Governor's discretion over appointing and removing Panel members at some future date, should it perceive a need to do so. See id. (noting that setting terms for Panel membership "may be a subject for future regulatory action"). 
restrictions on the Governor's discretion that will provide for a fair and balanced representation of interests. This could be done by (1) requiring the Governor to appoint persons with diverse viewpoints to the Panel, (2) granting the public greater participation in the selection process, and (3) linniting the Governor's power to reinove Panel ineinbers.

1. Under the Federal Advisory Coininittee Act (FACA), a federal advisory panel's inembership must be "fairly balanced in terms of the points of view represented and the functions to be performed by the advisory committee."136 Although FACA explicitly does not apply to state and local advisory coinmittees, ${ }^{137}$ HWA should adopt a sinnilar antistacking provision to limit the Governor's discretion over appointinents. A "fair balance" provision would not be effective, lowever, unless it specifically identifies which interests inust be represented on the Panel. Because FACA does not define what constitutes such a fair balance of viewpoints, the Act has in practice granted federal officials almost complete discretion in determining who is to serve on advisory cominittees. ${ }^{138}$ In order to clarify FACA's ainbiguous "fairly balanced" provision and limit discretion, soine federal agencies have set forth in their own regulations those interests that inust be represented on their advisory coinmittees. ${ }^{139}$ HWA slould likewise require the Governor to

136. 5 U.S.C. app. $2 \S 5(b)(2)$ (1988). For further discussion of FACA's fair balance requirement, see Ashford, Advisory Committees in OSHA and EPA, supra note 2, at 76-79; Cardozo, supra note 2, at 55; Gage \& Epstein, supra note 2, at 50,004-05.

Congress intended this FACA provision to reduce abuses, such as "stacking," involving committee membership. See House CoMm. ON Government OpERATIONS, THE ROLE AND EFFECTIVENESS OF FEDERAI AdvisORY COMMITTEES, H.R. REP. No. 1731, 91st Cong., 2d Sess. 19 (1970) ("There is [a] need to expand the base of participation and representation in the advisory system's decisionmaking processes.") (report issued two years prior to FACA's passage).

137. 5 U.S.C. app. 2 \&(c) (1988).

138. See National Anti-Hunger Coalition v. Executive Comm. of President's Private Sector Survey on Cost Control, 711 F.2d 1071, 1074 (D.C. Cir. 1983) (public-interest representatives need not be included on committee designed to provide government with private-sector management expertise); Hall v. Siegel, 467 F. Supp. 750, 755 (D. Ill. 1977) (equal rights amendment ratification coordination committee need not include more than one outspoken opponent of ERA); see also 60 Comp. Gen. 386, 395 (1981) (all interests need not be represented or represented equally to meet applicable balance of membership requirements, but courts should review each committee on a caseby-case basis to determine if balance requirement was met).

Because FACA's "fairly balanced" requirement is somewhat ambiguous, federal agencies often have been unwilling to include significant representation of public interest groups, such as environmentalists and consumer advocates, and have instead relied disproportionately on committee members with both direct and indirect contacts to private industry. Industrial interests have thus gained an unfair advantage in influencing advisory committee decisions. See Gage \& Epstein, supra note 2, at 50,004-05 (noting that federal agencies often have read FACA's balance requirement narrowly to require only social balance, in terms of race, gender, or geography, rather than political balance, in terms of economic or ideological viewpoints); see also Ashford, Advisory Committees in OSHA and EPA, supra note 2, at 77 (noting that most attention has focused on the balancing of "political, institutional, ethnic, or sexual bias or allegiance").

139. See generally 5 U.S.C. app. $2 \S 8$ (a) (1988) (authorizing federal agencies to promulgate regnlations that implement and enforce FACA's provisions). For example, OSHA requires that its 
appoint individuals who represent the various interests affected by Proposition 65. Unfortunately, Proposition 65 concerns a broad range of interests, including industry, labor, agriculture, local governments, consumers, and environmentalists. ${ }^{140}$ Moreover, each of these groups contain numerous factions that often disagree on issues relating to the regulation of toxic substances. Thus, even if HWA regulations specifically identified those general interests that should be represented on the Panel, it would be difficult to give each of then any sort of ineaningful representation without expanding the Panel beyond a manageable size. Nevertheless, a specific fair-balance provision would still guarantee a broader range of viewpoints than are provided for under HWA's current regulations.

2. HWA should amend its regulations to guarantee interested persons an opportunity to provide input into the selection process. In order to facilitate direct public involvement in the process, HWA should require the Governor to give notice prior to appointing a Panel inember and permit interested parties both to comment on candidates for membership and to suggest alternative experts who would be willing to serve. ${ }^{141}$ Although a notice and comment period would not in itself guarantee that the Governor would actually select anyone suggested by the public, it would at least provide an expanded and inore balanced hist of available experts. In addition, it would subject the Governor's selections to additional scrutiny before they begin service on the Panel. The Governor would thus be encouraged to include a broader range of viewpoints on the Panel. ${ }^{142}$

ad hoc committees which set regulatory standards for occupational hazards contain a balance of expert representatives from both labor and industry. 29 U.S.C. $\S 656($ b) (1982). Although the criteria OSHA uses to determine whether an individual represents a particular interest are not altogether clear, commentators generally agree that the OSHA provision has provided for fairer representation on OSHA's coinunittees than would otherwise exist. See, e.g., Ashford, Advisory Committees in OSHA and EPA, supra note 2, at $74-75$ (discussing the operations of OSHA committees).

140. See ANALysis of Proposition 65, supra note 16, at 15-18 (discussing economic impact of Proposition 65's provisions on several different industries); NosSAMAN, GuTHNER, supra note 15, at 157-217.

141. The notice and coininent procedures could be sinilar to those already employed by HWA to govern Panel proceedings. See supra notes 63-71 and accompanying text; see also Gage \& Epstein, supra note 2, at 50,005 (noting the effectiveness of similar procedures as voluntarily employed by federal agencies).

142. In fact, the Governor, with HWA's assistancc, made some effort to solicit recommendations for inembers from certain interested parties prior to the Panel's creation. ALERT: California Chamber of Commerce, supra note 31, at 3. While the recominendations received included some from environmental groups, two of which were accepted, it appears that the state made little or no effort to contact many groups that were directly affected by Proposition 65 . See supra note 34 and accompanying text. The first significant press report concerning the Panel's creation and the need to find qualified experts did not occur until a little over a month before the Panel's first ineeting, at which point it was probably too late for concerned citizens to affect the Governor's membership decisions. See San Francisco Chron., Feb. 10, 1987, at 8, col. 1. 
3. HWA should limit the Governor's power to remove Panel members solely for political reasons. As noted previously, the Agency rejected both good-cause and fixed-term requirements on the ground that they did not "appear necessary for scientists who are making judgments on matters of science." 143 But, since the Panel clearly makes trans-scientific judgments on matters of policy, this rationale is invalid. Creating staggered, fixed terms would promote continuity in the Panel's decisionmaking, a goal that HWA has identified as important to a fair, efficient, and scientifically sound implementation process. ${ }^{144}$ Should a legitimate question of a Panel member's competence, conflicts of interest, or dedication to the committee's operations arise, a removal-for-good-cause provision would allow the Governor to replace the member in question with one better suited for Panel service.

\section{IV}

\section{The Regulations' EFFectiveness in ENSURing AGAINST IMPROPER INFLUENCE}

Because of the significant social and economic impact of the Panel's decisions, interested parties have a strong incentive to attempt to influence the members' decisions. The trans-scientific nature of the Panel's activities makes it particularly susceptible to such attempts. Although this imfluence is not inherently bad, no particular interest should be allowed to obtain an unfair opportunity to affect the Panel's decisionmaking to the exclusion of other interested parties.

Recognizing at least some of these dangers, HWA included in its regulations provisions designed "to ensure that the recommendations of the Panel are free of bias and undue influence." 145 For example, the regulations require Panel members to make annual disclosures of investments $\mathrm{m}$ businesses that deal with hazardous substances, and they require members in academic appointments to reveal their major sources of research funding. ${ }^{146}$ Thus, the regulations appear to reduce the risk that Panel members will vote according to their financial interests by requiring members to disclose those interests.

Given the trans-scientific nature of the Panel's decisionmaking, however, disclosure requirements alone cannot protect the Panel from every threat to its independent judgment. Interested parties, both inside

143. Statement of Reasons, supra note 8 , at 35.

144. See Transcript, 3rd Meeting, supra note 68, at 8 ("Clearly, for the sake of the credibility of the Panel and for the good of industry and public health, a process that is stablc, based on good science, and not subject to periodic fluctuations, is most desirable.") (statement of Dr. Steven Book, Panel Executive Secretary).

145. Statement of Reasons, supra note 8, at 36 .

146. See supra notes $45-49$ and accompanying text. 
and outside the government, may influence the Panel's decisionmaking by providing it with biased or incomplete technical information upon which to base its decisions. In addition, outside interests may take advantage of members' conflicts even after they have been disclosed. Finally, officials inside the government may compromise the Panel's independence by manipulating its decisionmaking processes and misusing its findings. HWA's regulations fail to adequately control these forms of outside and inside influence.

\section{A. Improper Outside Influence}

\section{Conflicts of Interest}

A conflict of interest occurs when an advisory committee member feels a strong allegiance to a private interest directly affected by the committee's decisions. ${ }^{147}$ While stacking arises out of an administration's desire to advance a particular ideological viewpoint through the selection of members for service on the committee, ${ }^{148}$ a conflict of interest generally arises out of an individual member's desire for personal gain through a special relationship with private interests. ${ }^{149}$ The member's relationship with the private interest nay be financial, such as a consulting position with an affected industry, ${ }^{150}$ or political, such as a leadership position in an environmental or industry lobbying organization. ${ }^{151}$ Although a member may ultimately decide an issue unfavorably to the outside interests with whom he is associated, he is unlikely to do so without first considering the effect such a decision could have on his relationship with those interests. ${ }^{152}$

Unfortunately, nearly every qualified scientific expert maintains some continuing relationship with private industry or with public interest groups, either as an investor, employee, consultant, or recipient of private research funds. ${ }^{153}$ As a result, it is nearly impossible for the govern-

147. For further discussion of the effect of conflicts of interest on advisory committee operations, see Brooks, supra note 1, at 55-56; Gage \& Epstein, supra note 2, at 50,006-07.

148. See supra notes 121-22 and accompanying text.

149. See J. PRIMACK \& F. vON HIPPEL, supra note 84, at 82 (discussing conflicts of interest on the committee that evaluated the herbicide 2,4,5-T); Gage \& Epstein, supra note 2, at 50,006 (general discussion of the conflict of interest problem).

150. See Wade, NAS Committee on Asbestos: Discovery of a Special Relationship, 193 SCIENCE 661 (1976) (discussing situation in which a member of the National Academy of Sciences' Subcommittee on Particulate Contaminants was forced to resign due to an undisclosed relationship with the Reserve Mining Company, a major producer of asbestos).

151. See Gage \& Epstein, supra note 2, at 50,007 (discussing efforts to screen the political affiliations of advisory committee members). It is often difficult to distinguish this more general type of conflict from questions of fair balance. See Ashford, Advisory Committees in OSHA and EPA, supra note 2, at 78-79 (discussing the relationship between the fair-balance and conflict-of-interest issues).

152. See Gage \& Epstein, supra note 2, at 50,006.

153. See Cardozo, supra note 2 , at 37 (conflicts are inevitable when agencies consult with 
ment to find scientists without potential conflicts to serve on advisory committees. ${ }^{154}$ The Panel is no exception. A number of its current members face potential conflicts of interest, either because they are privately employed or because they conduct academic research funded by grants from private parties that have a stake in the Panel's decisions. ${ }^{155}$ Moreover, two members of the Panel recently resigned following charges that they improperly favored the interests of the chemical industry during their tenure on the Panel. ${ }^{156}$ Although these charges have yet to be substantiated, they underscore a serious flaw in the way HWA's regulations currently deal with conflicts of interest.

Under present regulations, there exist no formal means by which concerned members of the public can raise the issue of conflicts of interest to Panel members. Nor do the regulations grant concerned citizens any form of redress should members vote in favor of the outside interests with which they are connected. ${ }^{157}$ Finally, the regulations do not require Panel members to disqualify themselves from decisions where they have conflicts. As a result, HWA's current regulations do not effectively address the problem of conflicts of interest.

In order to address such conflicts, HWA's regulations should authorize some group or individual to act in an oversight capacity. For example, the regulations could grant the executive secretary authority to prevent a Panel member from voting on an issue where a conflict appears likely. While not a voting member, the secretary must already work closely with the Panel, ${ }^{158}$ and thus would be well suited to investigate any allegations that a member had failed to disclose a potential conflict or had participated in a decision while under an actual conflict. The executive secretary could therefore both provide general oversight and relieve individual members of the pressure of making their own disqualification decisions.

qualified scientists since they are "certain to be heavily involved professionally and financially in the area in which their advice is sought"); Gage \& Epstein, supra note 2, at 50,006 ("Experts in a particular field are often dependent to some extent on government or industry contracts and grants.").

154. See Ashford, Advisory Committees in OSHA and EPA, supra note 2, at 78 (discussing problems with advisory committee members' "potential allegiances"); Gage \& Epstein, supra note 2, at 50,006-07 (discussing specific occurrences of conflicts of interest).

155. See supra notes 70-71 and accompanying text.

156. L.A. Times, June 30,1989 , pt. I, at 29 , col. 3.

157. Commentators have noted that advisory committees have generally failed to develop guidelines for addressing actual conflicts, should such conflicts arise. See Gage \& Epstein, supra note 2, at 50,007 (discussing the National Academy of Science's failure to change its procedures after an advisory committee member was forced to resign due to an actual confiict of interest).

158. See CAL. Code of Regs. tit. 22, § 12302(c) (1989). 


\section{Other Forms of Improper Outside Influence}

In addition to conflicts of interest, an advisory coininittee faces inore subtle threats to its independent judgment. Outside interests might provide a coinmittee with biased or incoinplete information intended to influence the committee's findings. ${ }^{159}$ The danger is that advisory coinmittee ineinbers inay defer to this information without first adequately investigating its scientific validity, and then incorporate the biased information into the coinunittee's final decisions.

At a typical Panel ineeting, ten to twenty spokespersons for environmental, consuiner, or industry groups testify as to one or inore of the issues up for consideration. ${ }^{160}$ In addition, the Panel receives reans of technical reports that evaluate and summarize the scientific evidence concerning the substances considered for listing. ${ }^{161}$ The Panel often refers to these reports during its deliberations on particular substances, ${ }^{162}$ and their content undoubtedly affects its final decisions.

There is, of course, nothing wrong witl encouraging public participation in the Panel's decisioninaking, so long as its inembers are aware of the sources of this information and are able to detect any bias. Indeed, the trans-scientific nature of the Panel's duties makes public participation in its operations desirable in order to ensure that all views are fairly represented. ${ }^{163}$ The teinptation for outside interests to attempt to influence the Panel's decisions is too great, however, to assume that they always provide it with complete and accurate information. ${ }^{164}$ Moreover, even if

159. See National Research Council, Decision Making in the Environmental Protection AgENCY 51-58 (1977) (discussing problems arising from EPA's dependence on regulated industries for its technical data); J. PRIMACK \& F. VON HIPPEL, supra note 84, at 77-78 (alleging that Dow Chemical attempted to mislead federal officials into not regulating its herbicide 2,4,5-T).

160. See, eg., Transcript, 3rd Meeting, supra note 68 (thirteen spokespersons addressed the Panel). Often the Panel will recommend a substance for listing with little or no public comment. There have been times, however, when a significant amount of information has been produced through oral testimony at Panel meetings. For example, three scientists argued against the classification of beryllium as a known carcinogen. See Transcript, 3rd Meeting, supra note 68, at 9199. While the record is unclear, it appears that they were representing private interests with a financial stake in keeping the substance off the Governor's list. Although the Panel did ultimately recommend beryllium for listing, the scientists successfully persuaded the Panel to limit the scope of its decision only to exposure by injection, rather than adopting a broader standard applying to multiple routes of exposure. See id. at 101-03.

161. Telephone interview with Dr. Brenda Eskenazi, supra note 75.

162. See, eg., Transcript, 3rd Meeting, supra note 68, at 97-99, 109-10, 125-26 (Panel review of studies on beryllium, alcohol, and cadmium).

163. See Ashford, Advisory Committees in OSHA and EPA, supra note 2, at 73-74 (noting the desirability of public participation in trans-scientific decisionmaking); Gage \& Epstein, supra note 2, at 50,007-09 (same).

164. For similar concerns regarding technical information supplied by private industry to EPA's science advisors, see J. PRIMACK \& F. vON HIPPEL, supra note 84, at 77-84 (discussing how manufacturers of the herbicide 2,4,5-T used distorted scientific evidence to delay regulatory action); NATIONAL RESEARCH COUNCIL, supra note 159, at 51 ("The impact of many decisions on industry 
these interests do not intentionally misrepresent data, they may make innocent mistakes in their presentations to the Panel. As a result, there is a significant danger that Panel members may rely on incorrect information.

Unfortunately, HWA's regulations do little to ensure that the Panel has the resources it needs to evaluate adequately the information provided by outside sources. The twelve part-time Panel members play an integral role in implementing a complex regulatory program. They have encountered difficulty in taking time off from their other coinunitments to evaluate the scientific merits of the data presented by outside interests, or to conduct their own research into the issues before the Panel. ${ }^{165}$ Although the Panel has alleviated this problem somewhat by creating subcommittees and by assiguing the background research on a number of substances to specific members, ${ }^{166}$ some Panel members still believe that they have been unable to give adequate consideration to the complex technical issues involved in substance evaluation. ${ }^{167}$ It is likely, therefore, that the Panel has relied on incorrect outside information, thus coinpromising its independent judgment, and that this reliance will continue under HWA's current regulatory regime.

Given the Panel's need for large amounts of technical information, it would be unwise to prevent it from using information provided by outside interests. The Panel's ability to evaluate the merits of such information, however, could be significantly improved if it were permitted to have its own technical staff. A technical staff could examine all relevant studies relating to a question before the Panel and summarize its findings for the Panel's consideration. In addition to serving as a check on incorrect or misleading outside information, the staff would allow the Panel's members to carry out their duties more efficiently.

Admittedly, a technical staff does present some drawbacks. First, the staff would increase the cost of operating the Panel and reduce the fiscal benefits of using independent advisors who essentially volunteer their time. A staff composed of independent contractors who would

creates a potential conflict of interest that may cause industry, either inadvertently or intentionally, to distort or withhold necessary information.").

165. Although the Panel may have at its service resources at HWA or other state agencies, reliance on these agencies raises questions of improper inside influence. See infra notes 168-201 and accompanying text.

166. As early as its second meeting, the Panel began assigning "categories" of substances to individual members deemed to have special expertise in their potential epidemiological effects. Transcript, Second Meeting of the Safe Drinking Water and Toxic Enforcement Act Scientifie Advisory Panel 101 (June 18, 1987) [hereinafter Transcript, 2nd Meeting]. In addition, pursuant to HWA's regulations, CAL CODE OF REGs. tit. 22, $\S 12302$ (c) (1989), the Panel has established subcommittees to develop criteria for identifying carcinogens and reproductive toxicants. See infra notes 205-08 and accompanying text.

167. Telephone interview with Dr. Brenda Eskenazi, supra note 75. 
work only when needed would nevertheless be cost effective. In the long run, the benefits of protecting the Panel's independent judgment would exceed the cost of maintaining a staff.

Second, Panel members may routinely defer to the findings of their technical staff, possibly creating soine of the same reliance problems that currently exist with information provided by private sources. The staff's findings, however, presumably would not reflect the same biases that often plague those of special-interest representatives. Moreover, in order to ensure that Panel meinbers and not their staff assistants make the final decisions, staff reports should include detailed rationales for their recommendations. A properly structured technical staff could assist the Panel's operations without compromising its independence.

\section{B. Improper Inside Influence}

HWA's current regulations also fail to alleviate the danger that the Panel's independent judgment may be affected by the government officials that it advises. Like private industry, policymakers have a strong interest in the findings of neutral scientific committees because advisory committees can "provide[ ] a facade of prestige which tends to legitimize all technical decisions" of the governinent. ${ }^{168}$ Government's desire to "legitimize"169 its science prograin can lead it to exert inproper influence in two ways: by manipulating a committee to recommend policies favorable to the officials' views, ${ }^{170}$ and by selectively accepting only favorable committee recommendations. ${ }^{171}$

\section{Manipulation of Decisionmaking}

The first form of legitinizing involves direct attempts by government officials to manipulate a committee's internal decisionmaking processes. Even officials that appoint a balanced cominittee inay later try to influence the committee's decisions as particular issues arise. Such infiuence may be subtle, as when an agency supplies a coinmittee with biased information so that its members will support the agency's views, ${ }^{172}$ or it may be explicit, as when an agency sets a committee's

168. Perl, supra note 2, at 270.

169. See J. PRIMACK \& F. VON HIPPEL, supra note 84, at 31 (the authors' general section on the science advisory system is entitled “Advising or Legitimizing?"); Perl, supra note 2, at 270; see also Ashford, Advisory Committees in OSHA and EPA, supra note 2, at 76-77 (discussing how advisory committees may be used to "rubber stamp" government decisions).

170. See Ashford, Advisory Committees in OSHA and EPA, supra note 2, at 79 (an advisory committee "must be provided the necessary independence within which to pursue its work").

171. See id. at 79 (government officials may "simply ignore" advice with which they disagree); Perl, supra note 2, at 267-68 (contending that officials tend to ignore advisory committee recommendations that conflict with existing policies).

172. Cf. National ResearCh CoUNCIL, supra note 159, at 47.48 (explaining the advantages of genuinely independent committee review of agency decisions). 


\section{meeting agendas and procedures. ${ }^{173}$}

When trans-science is at issue, a fine line must be drawn between legitimate attempts to inform the committee's members and illegitimate attempts to interfere with their independent judgment. ${ }^{174}$ While there is nothing inherently wrong with government officials attempting to persuade an advisory committee to recommend policies they believe to be in the public interest, their influence should not interfere with the committee's exercise of its own independent judgment. ${ }^{175}$ Otherwise, the committee becomes a mere scientific facade for politically motivated decisions.

One must be particularly wary of legitimizing when an agency uses a scientific advisory committee to review the technical merits of the agency's regulatory proposals, such as when HWA asked the Panel to review its "significant risk" standards. ${ }^{176}$ Since the purpose of independ-

173. Ashford, Advisory Committees in OSHA and EPA, supra note 2, at 79 ("If advisory committees have insufficient autonomy to determine the issues they will consider, important issues may be overlooked, and the advisory committee may cease to function as an independent body.").

174. See id. at 74 (noting that the distinction "between fact finding and fair process . . . begins to blur" when advisory committees consider trans-scientific questions); Ashford, The Role of Advisory Committees, supra note 2, at 167 (same).

For example, if officials establish an advisory committee to identify potential locations for a nuclear waste disposal site, there is nothing wrong with their requesting that the committee take into account preset criteria such as proximity to population centers, availability of land, or cost. These are predetermined political decisions that merely set the trans-scientific parameters for the committee's decisionmaking: The committee ultimately is to determine the best sites within those parameters. If, however, officials subsequently provide the committee with significant information about sites in New Mexico and Nevada without corresponding data on other locations, they may interfere with the committee's independent judgment by influencing the committee to decide based on factors outside of the pre-established criteria.

175. In practice, it is probably impossible to determine the extent to which government officials influence a committee's decisions. There usually are no "smoking guns" or explicit admissions of attempts to manipulate a committee, and agencies are often unwilling or unable to document the entire flow of information between a committee and agency officials. See Gage \& Epstein, supra note 2, at 50,007-09 (noting that closed meetings conducted by advisory committees make it difficult to determine what sources influence recommendations); Perl, supra notc 2, at 269-70 (noting that many communications between government officials and their advisory committees are kept confidential). In addition, due to the complexity of many issues considered by scientific advisory committees, it is usually impossible to tell what motivates committee members to decide the way they do on any given issue. Consequently, one often finds only circumstantial evidence of legitimizing.

176. See supra notes $106-21$ and accompanying text. It is typical administrative practice for agencies to use their advisory committees to evaluate the technical merits of proposed regulations before they are promulgated. See NATIONAL RESEARCH COUNCIL, supra note 159, at 45.51 (discussing EPA's use of outside scientists to review the technical merits of Agency programs); Ashford, Advisory Committees in OSHA and EPA, supra note 2, at 74-76 (discussing the roles of EPA's and OSHA's advisory committees in regulatory decisionmaking).

For example, the EPA uses its Science Advisory Board to review and propose standards for implementing a number of federal acts. See U.S. Environmental Protection Agency, Advisory Committee Charter: Science Advisory Board, in U.S. ENVTL. PROTECTION AgencY, U.S. Environmental Protection Agency Advisory Committees: Charters, Rosters and ACCOMPLISHMENTS 33 (1986). In addition, the EPA Board is in charge of "[r]eviewing and 
ent advisory committee review is to provide an expert second opinion on regulatory proposals, the review will be most effective if the committee can conduct its evaluation free from agency influence. ${ }^{177}$ Only then can one be sure that the committee's members really examined the agency's proposals, rather than merely deferring to the agency's judgment.

HWA's regulations currently do little to ensure against improper governmental interference with the Panel's independent decisionmaking. Nevertheless, the extent to which state officials have interfered in the past or are likely to interfere in the future with the Panel's independent judgment is unclear. Some critics have charged that insiders have already manipulated the Panel, ${ }^{178}$ using "the inantle of science" created by the Panel to forward their own political goals. ${ }^{179}$ Yet, in spite of the critics' charges, the Panel has shown some independence from state officials im its decisionmaking. For example, the Panel has decided to estabhish de minimis levels below which a carcinogen or reproductive toxicant will not be considered hazardous. ${ }^{180}$ The de minimis levels will be similar to the "significant risk" standards found in Proposition 65's exposure warning requirements, ${ }^{181}$ but they will apply to all of Proposition 65's provisions, including its restrictions on the discharge of hazardous substances into the environment. State officials had repeatedly asked the Panel not to qualify its designations of liazardous substances. They argued tliat listing a substance under Proposition 65 requires a simple "yes-no" decision: either a substance belongs on the Governor's hist or it does not. ${ }^{182}$

advising on the scientific and technical adequacy of Agency programs, guidelines, methodologies, protocols, and tests." Id. at 34.

177. NATIONAL RESEARCH COUNCIL, supra note 159, at 47-48 (stating that independent outside review guards against inadvertent error and provides more balanced treatment of scientific and technical information); Ashford, Advisory Committees in OSHA and EPA, supra note 2, at 79 ("The committee must be provided the necessary independence within which to pursue its work ....").

178. See, e.g., Meyerhoff, supra note 9 (stating that the Governor has used the Panel to "thwart the will of the electorate").

179. Id.

180. Transcript, 3rd Meeting, supra note 68, at 20-33 (statement of Panel member Dr. Bruce Ames) (discussing the inability of science to determine risks at relatively low dosages of a potentially toxic substance); see also Carrick, supra note 73, at 7 ("A mere listing of . . . chemicals does not provide useful or even scientifically valid decisionmaking information either to the regulated community or to the public, and may indeed seriously misinform the public of the actual risk associated with particular chemical exposures.").

Additionally, the Panel has recommended listing hazardous substances in terms of routes of exposure, such as by designating beryllium as a known carcinogenic hazard by injection, but not by ingestion, inhalation, or dermal exposure. Transcript, 3rd Meeting, supra note 68, at 74-108.

181. See supra notes $106-21$ and accompanying text.

182. See, e.g., Transcript, 3rd Meeting, supra note 68, at 5-11 (statement of Dr. Steven Book, Panel Executive Secretary) (discussing the drawbacks of the Panel making determinations beyond merely recommending chemicals for listing); id. at 81 (statement of Robert D. Tousignant, Counsel for the Panel and Chief Assistant Counsel, Department of Health Services) ("It seems clear, based on the statute, that the obligation to list or not list a chemical is without qualification."); Transcript, 
But, in direct contravention of HWA's instructions, the Panel formally adopted a resolution that de minimis levels should be included for each cheinical identified. ${ }^{183}$

The de minimis risk episode denionstrates that the Panel will soinetimes resist overt attempts by HWA officials to influence its decisions. Nevertheless, the Panel's members should not have to face such pressure from agency officials. Furthermore, there reinains the possibility of other, less obvious, forms of manipulation. Such manipulation is difficult to detect, and inay not become apparent until after the Panel has been in operation for a longer period of time. In light of this uncertainty, the following discussion examines two inethods that state officials may use to influence the Panel's decisioninaking, and then suggests a number of changes to HWA's regulations to reduce the danger that the state will interfere with the Panel's independence.

\section{a. Government-Provided Information and Advice}

The Panel currently depends on scientists in HWA and other state agencies for a significant amount of its technical information. ${ }^{184}$ Information submitted by the state, hike that provided by private sources, is often both necessary and beneficial to the Panel's decisionniaking. Nevertheless, HWA should adopt measures to ensure that Panel menibers do not rely on government-provided information that has not been independently evaluated. The need to evaluate governinent-supplied information is particularly strong when the information provided relates to transscientific policy questions. While critics have yet to charge directly that state officials have provided information designed iniproperly to influence the Panel's decisions, at least one member has noted that the information has occasionally been technically flawed. ${ }^{185}$

In order to reduce the danger that its nembers will rely too heavily on scientific data provided by the goverunient, the panel should have

1st Meeting, supra note 70, at 88 (statement of Mr. Tousignant) ("[F]or purposes of listing for the proposition, I think [a substance is] either on or off the list."); id. at 90 (statement of Mr. Tousignant rejecting contention that substances can be listed by routes of exposure).

183. See Transcript, 3rd Meeting, supra note 68, at 33-74 (presentation of Dr. Ames' "Caveat" establishing policy of setting de minimis levels of exposure). The "Caveat" is reprinted in Prop. 65 News, Sept. 1987, at 3. See also SAP Holds its Third Meeting, Prop. 65 NEwS, Sept. 1987, at 1 ("[T] he Governor's Science Advisory Panel on Proposition 65 for the first time openly ignored the instructions of the Health and Welfare Agency.").

184. Kizer, Warriner \& Book, supra note 3 , at 952 (noting that the Panel is aided by HWA and other state agencies); Transcript, 2nd Meeting, supra note 166, at 58-59 (statement of Dr. Stephen Book, Panel Executive Secretary) ("The state agencies are ... providing the exposure assessments and the environmental fate assessments....").

185. For example, one Panel member serving on the Subcommittee on Reproductive Toxicants noted that HWA and DHS scientists omitted significant research data that indicated the need for stricter standards for identifying developmental toxicants. Telephone interview with Dr. Brenda Eskenazi, supra note 75. 
access to an independent staff, including a part-time legal advisor with no direct connection to HWA or the Governor's office. An independent technical staff would assist the Panel's nembers in reviewing scientific data provided thein, locating honest mistakes as well as any deliberate atteinpts to mislead. ${ }^{186}$ Furthermore, additional efforts should be made to ensure that communications between HWA officials and the Panel's members become a matter of public record. In compliance with the California Public Records Act, ${ }^{187}$ current HWA regulations require that "[a]11 official correspondence to or from the Panel, any subcommittee, or any member of the Panel shall be available for public inspection."188 While this provision accounts for the detailed reports submitted for the Panel's consideration, it probably does not require disclosure of routine, informal conversations between individual Panel members and state officials. Yet, these informal communications may relate directly to a inatter under the Panel's consideration and could well influence the meinber's opimion. HWA regulations should be amended to require disclosure of all substantive information exchanged in informal commumications between Panel members and state officials that relates to a matter before the Panel. The communications themselves need not be public, so long as their content is disclosed before the Panel takes final action on the issue discussed in the commumication.

\section{b. Control of Panel Agenda and Procedures}

HWA also influences the Panel's operations through control over its agenda and decisionmaking procedures. Currently, HWA's regulations are silent as to who has the authority to set the Panel's agenda. ${ }^{189}$ In a brief discussion at its first meeting, state officials insisted that the Panel would have complete discretion over the topics it considers. ${ }^{190}$. Nevertheless, the Panel has with very few exceptions addressed only those issues presented to it by HWA officials. ${ }^{191}$ The Agency has therefore effectively controlled the Panel's decisionmaking agenda during its first two years of operation.

HWA's control over the Panel's agenda is proper when the Panel acts in its advisory capacity. As noted previously, activities designed to

186. See supra text accompanying notes $167-69$.

187. CAL. Gov'T CODE $\$ \S 6250-6265$ (West 1980 \& Supp. 1989).

188. CAL. CODE OF REgS. tit. 22, § 12302(d) (1989).

189. See id. (merely stating that the Panel's agenda should be made available to the public).

190. Transcript, 1st Meeting, supra note 70, at 91 (statement of Robert D. Tousignant, Counsel for the Panel).

191. One notable exception was the Panel's acceptance of Dr. Bruce Ames' "Caveat" stating it would recommend substances for listing by routes of exposure and subject to de minimis levels below which a substance should not be considered hazardous. See supra notes 180-83 and accompanying text. 
help state officials carry out their duties under Proposition 65 usually require some initiating action by state officials. The Panel's advisory duties are to evaluate regulatory standards and definitions proposed by HWA and advise HWA and the Governor on technical issues concerning Proposition 65's implementation. ${ }^{192}$

State officials should not, however, have control over the Panel's decisionmaking agenda when it acts as the state's qualified experts and identifies hazardous substances for the Governor's list. This activity is not carried out for the benefit of HWA or the Governor and is binding on state officials. ${ }^{193}$ The identifications represent the core of the Panel's statutory responsibilities as the state's experts, and it should be solely up to the Panel's members to determine the order in which chemicals are considered for histing. Since the Panel has recommended for listing nearly every substance it has considered, many substances may still be off the Governor's list only because the Panel has not yet had the opportunity to consider them at a meeting. The agenda for evaluating substances, therefore, is critical to the Panel's role as the state's experts.

Regrettably, HWA's current regulations have failed to ensure that the Panel sets its own agenda for identifying hazardous substances. Prior to its first meeting, HWA established a priority list for the Panel to use when considering potential carcinogens and reproductive toxicants for listing. ${ }^{194}$ The Panel's chairperson agreed sometime prior to the meeting that the committee would follow this list, and no public discussion by the full Panel concerning the merits of this approach was ever conducted. ${ }^{195}$ Because it took the Panel about eighteen months to consider all of the chemicals on the priority hist, HWA effectively determined the scope of one of the Panel's primary statutory responsibilities. ${ }^{196}$

In order to protect the Panel's independence as the state's experts, HWA should amend its regulations to authorize the Panel to establish its own agenda for evaluating chemicals. The regulations should permit the Panel to adopt a proposed agenda only after opportunity for public comment. Furthermore, the amended regulations should make clear that the final determination of which chemicals the Panel evaluates for listing rests solely with the Panel's meinbers. While the amended regulations

192. See supra notes $57-60$ and accompanying text.

193. See supra notes $54-61$ and accompanying text.

194. Transcript, 1st Meeting, supra note 70, at 6-7 (statement of Robert D. Tousignant, Counsel for the Panel) ("[T]he Health and Welfare Agency has issued a list of 201 candidate chemicals for the panel's review.").

195. Id. at 7 ("Dr. Kilgore, the Chairman of the panel, has made a public commitment to have [the 2011 chemicals reviewed by the panel ....").

196. At present, the Panel is exercising some greater degree of control over setting its agenda for identifying chemicals. HWA's current regulations, however, offer no assurances that this practice will continue. 
may still permit HWA and the Governor to request the Panel's advice on other aspects of Proposition 65's implementation, they should prohibit state officials from imterfering with its members' primary duties as the "state's qualified experts."

\section{Selective Acceptance}

The second form of legitimizing occurs when government officials accept only those advisory committee recommendations that coincide with agency policies, thus ignoring all recommendations to the contrary. ${ }^{197}$ Government officials' ability to selectively accept advisory committee decisions hinges on two issues: (1) their authority to reject the committee's findings and (2) the political acceptability of such a rejection. For example, if the public is unaware of the committee's recommendations, officials will be able to ignore them because there is no need to explain the disparity between the expert advice and actual government policies. ${ }^{198}$ Should officials accept a committee's findings, they can publicize them widely. If they reject the findings, they can deny that the advice was ever received.

It appears that the Panel's designations of substances as known carcimogens and reproductive toxicants have the force of law and, therefore, that state officials must accept them without question. ${ }^{199}$ There is no risk of selective acceptance as to these decisions. On the other hand, the danger of selective acceptance does exist for the Panel's nonbinding policy advice. Even members of the Panel have expressed concern that their advice may be ignored when it conflicts with state officials' political views. $^{200}$

Yet, neither HWA nor the Governor has even hinted about rejecting

197. Officials tend to ignore committee decisions when (1) the decisions are contrary to existing agency policies, (2) the decisions would expose the agency to political attack, and (3) the decisions run counter to the desires of special interests which have influence over the agency's decisionmaking. Perl, supra note 2, at 267; see J. PR1MACK \& F. vON HIPPEL, supra note 84, at 33-35 (illustrating how officials may seleetively accept advisory committee recommendations by publicizing those they support and concealing those they oppose); T. WolANIN, supra note 122, at 157-67 (citing cases in which Presidents have selectively ignored their advisory committee recommendations); Gage \& Epstein, supra note 2, at 50,010 (noting that the FACA "does not require agencies to follow advisory committees' advice."); see also Ashford, Advisory Committees in OSHA and EPA, supra note 2, at 7576 (noting that OSHA's ad hoc standard-setting committee's recommendations have received mixed responses from the Agency).

198. See J. Primack \& F. voN Hippel, supra note 84, at 33-36 (discussing the role of confidentiality in promoting abuse of the advisory committee system); Perl, supra note 2, at 269-70 (same); Gage \& Epstein, supra note 2, at 50,009-10 (discussing the dificulty in accessing advisory committee reports and other records).

199. See supra notes 54-55 and aceompanying text.

200. Transcript, 3rd Meeting, supra note 68, at 89 (statement of Panel member Dr. W.L. Spangler) (expressing concern that HWA might simply ignore the Panel's qualifications on its listing decisions). 
a Panel advisory decision, in spite of the Agency's explicit reservation of its right to do so at any time. ${ }^{201}$ This is not surprising in light of the significant publicity that the Panel's decisions receive and the state officials' praise for its qualifications and role in the implementation process. It is unlikely that state officials could reject the Panel's decisions without raising public criticism.

Nevertheless, even though it would be difficult for state officials to quietly ignore or reject the Panel's decisions, HWA should amend its regulations to provide better guidance for resolving such a situation. Under the current regulations, the Agency need not state its rationale for rejectimg a recommendation; nor must it return the issue to the Panel for further consideration. This lack of regulatory control creates the potential for political turmoil should HWA fail to adopt a widely supported Panel proposal. The Agency's best interests require that it prepare for such a conflict before it arises.

HWA's regulations should require Agency officials to state clearly their rationale for rejecting Panel opinions, and to offer the Panel an opportunity to respond before final action is taken. Not only would this ensure that state officials' decisions are reasonable, but also that the Panel becomes aware of how it could change its methods of decisionmaking to serve better the government's needs. By these means, the danger of selective acceptance could be greatly reduced.

\section{$\mathrm{V}$ \\ HWa's Regulations and Panel Decisionmaking}

Because trans-scientific questions require the Panel to act as both scientists and regulators, HWA's regulations must strike a balance between promoting good scientific practices and good regulatory practices. While HWA has made some efforts to obtain this balance, the regulations fall far short of addressing the needs of science and public policy. In particular, HWA's failure to appreciate the trans-scientific nature of the Panel's activities has led to the regulations' shortcomings in governing the Panel's decisionmaking. This Part examines how HWA's regulations have failed to provide the decisionmaking forum necessary for the Panel to carry out its duties as the state's qualified experts and suggests how to amend them in order to improve the Panel's operations in the future.

\section{A. Establishing Regulatory Standards}

Current HWA regulations permit-rather than compel-the Panel to establish regulatory standards, such as the definitions of carcinogenic-

201. See Statement of Reasons, supra note 8 , at 38 . 
ity and reproductive toxicity. ${ }^{202}$ Shortly after the Panel began identifying individual chemicals to be included on the Governor's list, a number of its members recognized that it was both inefficient and scientifically unsound to do so without adequate scientific definitions. ${ }^{203}$ The members feared that, without proper standards, they would have to reconsider this difficult issue each time they considered another chemical for listing; thus wasting valuable time and possibly producing inconsistent results.

HWA rejected provisions that would have required the Panel to establish such standards:

This requirement [that the Panel identify chemicals only under a predetermined standard] does not appear necessary. Logically, the Panel must employ some kind of standard in order to review chemicals, and that standard will be the product either of their own proposals or their review of standards employed by other agencies or organizations. There does not appear to be a need here to state the obvious. ${ }^{204}$

This view reflects HWA's behef that the Panel would engage in pure scientific decisionmaking that would invariably result in the scientifically "correct" answer. Thus, HWA officials believed that requiring the Panel to develop and publicly commit itself to set standards was unnecessary.

The first two years of the Panel's operations, however, illustrate that it was not "obvious" that the Panel would establish scientific standards with which to identify hazardous substances. In order to facilitate the development of standards, the Panel established two subcommittees at its first meeting, the Subcommittee on Reproductive Toxicity and the Subpanel on Carcinogenicity. ${ }^{205}$ Although the Subpanel on Carcinogenicity

202. See CAL. CoDE of REGS. tit. 22, § 12305(d) (1989) ("[T] he Panel may . . . [r]eview or propose standards and procedures for determining carcinogenicity and reproductive toxicity of chemicals.").

203. See Transcript, 1st Meeting, supra note 70, at 105 (statement of Dr. Wendell Kilgore, Panel Chairman) ("[T]he panel, at some point in time, needs to make a decision on the criteria that we will use to select whether or not a chemical is or is not carcinogenic."); see also id. at 110-11, 11721 (statements of Panel members Drs. Herschel Emmett Griffin, D. Warner North, Dorothy T. Burk, and Brenda Eskenazi in support of developing guidelines for identifying carcinogens and reproductive toxicants).

In addition, scientists who have testified before the panel have expressed the need for general guidelines. See, e.g., Transcript, 3rd Meeting, supra note 68, at 113 (testimony of Robin Shapiro, spokesperson for the Wine Institute, the Beer Institute, and the Distilled Spirits Council, summarizing statement of Dr. E. Marshall Johnson, Professor and Chairman, Department of Anatomy, Jefferson Medical College) (" $[I]$ t is wholly inappropriate for this Panel to proceed with a substantive consideration of any chemical ... until this Panel has first adopted specific criteria which would be the basis for evaluating substances for the list of reproductive toxicants."); Transcript, 1st Meeting, supra note 70, at 44-45 (testimony of Dr. John Moore, Assistant Administrator of Pesticides and Toxic Substances, EPA) (suggesting that the Panel's identification of chemicals "should be guided by some type of a systematic process, which, hopefully, stimulates consistent evaluations that are performed with scientific rigor").

204. Statement of Reasons, supra note 8, at 38.

205. See Transcript, 1st Meeting, supra note 70 , at 129-30 (creating the Subcommittee on 
quickly developed standards acceptable to the full Panel, ${ }^{206}$ the Subcommittee on Reproductive Toxicity's proposal received almost no support from Panel members. ${ }^{207}$ In particular, Panel members were concerned about the uncertainties surrounding labelling agents as reproductive toxicants and wanted to conduct further research prior to promulgating a proposed standard. ${ }^{208}$

The failure of the Subcommittee to develop satisfactory standards is not surprising, given the trans-scientific nature of the Panel's activities. The Panel's members have not been able to agree on the significance of studies involving laboratory animals, or of evidence from studies involving very high doses to normal levels of exposure. ${ }^{209}$ Both issues are the

Reproductive Toxicity); Science Advisory Panel Members: Subcommittee on Reproductive Toxicity, Prop. 65 NEws, Oct. 1987, at 3 (biographical reports on the members). The subcommittees were created pursuant to CAL. CoDE of RegS. tit. 22, § 12302(c) (1989).

206. After considering various methods for identifying carcinogens previously developed by a number of authoritative bodies, including the International Agency for Research on Cancer (IARC) and California's Department of Health Services, the Subpanel recommended standards similar to those used by the EPA in its Guidelines on Carcinogenic Risk Assessment, 51 Fed. Reg. 33,992 (1986).

The EPA Guidelines categorize potential carcinogens with respect to the adequacy of scientific evidence concerning the effects on humans and animals at different levels of exposure. According to the EPA, "sufficient evidence" of carcinogenicity exists when there is evidence of a strong causal relationship between the agent and the resulting cancer. Id. at 33,999. "Limited evidence" is that which indicates the possibility of a causal relationship, but still does not preclude alternative explanations, such as chance or experimental bias. Id. Following EPA's method of classification, the Panel decided to consider for listing only those substances for which there exists sufficient evidence of cancer in animal subjects, or sufficient or limited evidence in human subjects. Transcript, 2nd Meeting, supra note 166, at 64-69.

207. The Subcommittee recommended defining a "known" reproductive toxicant as a substance for which there exists either "[s]ufficient evidence of adverse reproductive effects in people," or evidence from studies involving laboratory animals such that "effects in people may be reasonably anticipated." Transcript, 2nd Meeting, supra note 166, at 17-18. The Panel members worried that this proposed definition was so broad that it could result in the listing of thousands of chemicals, diluting the effectiveness of regulating those products that pose more serious threats of causing reproductive disorders. Id. at 30-31 (remarks by Panel member Dr. F. Jay Murray). In fact, one Panel member half-seriously expressed concern that the proposal would lead to the absurd result of labeling birth control devices as reproductive toxicants. Id. at 21 (remarks by Panel member Dr. Bruce Ames).

208. See id. at 17-38; see also ANAlysis of Proposition 65, supra note 16, at 5 ("Unlike cancer-causing agents, no professional consensus exists regarding the definition of reproductive toxics.") (emphasis omitted); NosSAMAN, GUTHNER, supra note 15, at 75.

209. The debate over the effectiveness of various methods for testing reproductivc toxicity and carcinogenicity has flared up on a number of occasions at Panel meetings. See, e.g., Transcript, 2nd Meeting, supra note 166, at 23, 31-34, 57-58; see also San Francisco Chron., Feb. 27, 1987, at 28, col. 1 ("The use of [animal] tests, although widely accepted as the basis for demonstrating carcinogenicity, has emerged as a pivotal issue as Proposition 65 is put into effect.").

While the use of laboratory animals in scientific testing requires no explanation, high-dosage experimentation is likely to be less well understood. High dosage experimentation is necessary when rates of incidence of cancer or reproductive toxicity caused by a particular substance are relatively low at normal levels of exposure, such as one incident in a million exposures. In testing these substances, scientists would have to expose millions of laboratory animals at normal levels of exposure in order to determine such a rate with reasonable accuracy. Needless to say, such a "mega- 
subject of continuing debates within the scientific community, and have been coinpounded by the relative scarcity of scientific information on reproductive toxicants. While scientific knowledge of carcinogenicity has progressed far in recent years, the scientific community is just beginning to understand the nature of reproductive dangers. Few coinprehensive studies have been conducted that address the wide-ranging effects of chemicals on human fertility and prenatal development. ${ }^{210}$ Consequently, the Panel's difficulty in developing workable standards is understandable.

While the Subcommittee struggled to develop standards, the Panel identified thirteen additional substances as "known" reproductive toxicants. ${ }^{211}$ To nuake these identifications, the Panel did exactly what its members had said it should not do-it redefined reproductive toxicity each time it considered another substance. Certainly, identifying these substances by applying soine type of articulated standard, however provisional, would have been better than using no uniform standard at all. Authoritative federal agencies such as the EPA and OSHA have devised provisional guidelines for their regulatory programs, ${ }^{212}$ and no provision

mouse" experiment would be both expensive and impractical. See Schneiderman, Mantel \& Brown, From Mouse to Man-Or How to Get From the Laboratory to Park Avenue and 59th Street, 246 ANNALS OF THE N.Y. ACAD. OF SC1. 237, 241 (1975). Consequently, scientists often choose to expose fewer animals at much higher rates and then extrapolate their results to normal levels of exposure by way of a "dose-response curve," relying on the widely held assumption that there exists a direct correlation between dosage levels and numbers of incidents. See McGarity, supra note 85, at 733-36.

Although the existence of a dose-response relationship is generally accepted, the scientific validity of extrapolations involving specific substances is subject to debate. See EPA Guidelines for Carcinogen Risk Assessment, 51 Fed. Reg. 33,992, 33,996-34,003 (1986) (discussing conflicts between differing extrapolation models); Latin, supra note 86, at 98-100 (same); Mazur, Disputes Between Experts, 11 Minerva 243, $251-58$ (1973) (same).

210. See Nossaman, Guthner, supra note 15 , at 91 ("There is no clear definition of a 'reproductive toxin." "); see also id. at 75-77.

211. See CAL. CODE OF Regs. tit. $22, \S 12000$ (1989). Three other substances included on the list during that time came under the minimum listing requirements of CAL. HEALTH \& SAFETY CODE $§ 25249.8$ (a) (West Supp. 1989) and thus were not considered by the Panel. See supra note 26 and accompanying text.

Admittedly, most of the reproductive toxicants identified by the Panel during this period, such as Diethylstilbestrol (DES), are so obviously hazardous to human reproduction that they undoubtedly would have been included under any standard. Thus, it is difficult to charge that the Panel should not have identified any of the substances that it did. Nevertheless, the Panel's failure to establish scientific criteria was inexcusable in light of the potentially enormous impact of its decisions on public health and the state's economy, particularly since HWA has emphasized maintaining a process that is "predictable, consistent and fair." See Transcript, 3rd Meeting, supra note 68, at 6.

212. For example, the EPA issued its Guidelines for the Health Assessment of Suspect Developmental Toxicants in conjunction with its Guidelines for Carcinogen Risk Assessment. See EPA Guidelines for the Health Assessment of Suspect Developmental Toxicants, 51 Fed. Reg. 34,028 (1986). However, the EPA's standards address only the developmental aspects of reproductive toxicity (i.e., mutagenic and teratogenic substances that cause birth defects); they do not address issues of fertility. By contrast, other authoritative bodies have opted for broader definitions of reproductive toxicity, such as OSHA's Hazard Communication Standard, which 
in Proposition 65 prohibited the Panel from adopting any one of these approaches as an interim measure while it formulated its own standards. ${ }^{213}$ Critics thus rightfully described the Panel's policy as a "we will know it when we see it" standard that was not only inefficient and difficult to predict, but also may have resulted in inconsistent evaluations of the reproductive hazards posed by different substances. ${ }^{214}$

Although perhaps correct in viewing the Subcommittee's guidelines as unsatisfactory, the Panel erred in allowing the Subcommittee eighteen more months to develop a workable proposal. ${ }^{215}$ The Panel's members presumably believed that the Subcommittee needed this additional time to develop adequate and comprehensive standards. But, in its efforts to derive a scientifically "correct" standard, the Panel ignored the transscientific policy implications of failing to act promptly.

Had HWA been properly overseeing the Panel's operations, it would have reahzed within a few months that the Panel was trying too hard to derive a good scientific answer to the reproductive toxicity standards issue, at the expense of pressing regulatory needs. The Agency should

appears to include both the developmental and fertility aspects of reproductive toxicity. 29 C.F.R. $\S 1910.1200$ app. A (1988) ("Health Hazard Definitions"); see also NossamaN, GuTHNER, supra note 15 , at $91-93$.

213. Because the distinction between the EPA and OSHA standards rests primarily on decisions within those agencies to adopt either broad or narrow definitions of reproductive toxicity for policy reasons, neither standard is "more correct" from a purely scientific standpoint. See NosSamaN, GUTHNER, supra note 15, at 75-78, 91-93. Because Proposition 65 offers no standards of its own for reproductive toxicity, the statute's plain language does not appear to favor one approach over the other. Therefore, the Panel could have adopted either approach, or one completely different, in establishing its own standards for classifying reproductive toxins.

214. See Transcript, 3rd Meeting, supra note 68, at 113. Ironically, the Panel finally agreed on a provisional standard for identifying reproductive toxicants that relies heavily on those standards currently used by the EPA and OSHA. See Criteria for Recommending Chemicals for Listing as "Known to the State to Cause Reproductive Toxicity": Recommendations of the Subpanel on Reproductive Toxicity, Safe Drinking Water and Toxic Enforcement Act of 1986 Scientific Advisory Panel (Nov. 21, 1988) [hereinafter Interim Criteria] (adopted by the Panel on Dec. 16, 1988) (opting for OSHA's relatively broad definition of reproductive toxicity that includes substances that threaten to cause either birth defects (developmental effects) or infertility and other prenatal disorders (reproductive effects)); see also EPA Guidelines for the Hcalth Assessment of Suspect Developmental Toxicants, supra note 212 (EPA's developmental-effects criteria mirrored by the Panel's). Even this standard is incomplete, however; the Panel and the Subcommittee are waiting for the EPA to finish additional guidelines for evaluating the effects of suspected reproductive toxins on fertility and prenatal disorders. See Interim Criteria, supra, at 4.

While this decision may improve consistency between federal and state standards, and provide the Panel with the benefit of being able to rely on the EPA's findings, it means that the Panel continues to identify reproductive toxicants in the absence of completed standards. For example, since the adoption of the interim criteria by the Panel on Dec. 16, 1988, 16 new substances have been added to the list of reproductive toxicants. See CAL. CoDE of REGS. tit. 22, § 12000 (1989).

215. In fact, the Subcommittee's chairperson had promised the full Panel that the revised standards would be ready early in the fall of 1987. Transcript, 3rd Meeting, supra note 68, at 109 (statement of Panel member Dr. Andrew Hendrickx). Fall camc and went, however, and it was not until November 1988 that the Subcommittee was able to present the Panel with even a partially completed standard. See Interim Criteria, supra note 214. 
have either proposed an interim standard itself or asked the Panel to develop an interim standard. Of course, any effort by HWA to dictate how the Panel should undertake its decisionmaking interferes to soine extent with the free exercise of the Panel's expertise. Thus, perhaps HWA should be commended for not interfering with the Panel's independent judgment on this particular issue. Yet, when it became apparent that the Panel was unable to rectify the dichotoiny between scientific and regulatory decisionmaking, HWA should have stepped in and taken a nore active role in guiding the Panel to a socially desirable solution.

In order to avoid a reoccurrence of situations such as the reproductive-toxicants-standards episode, HWA should annend its regulations to require Agency officials to impose constraints on how long the Panel nnay consider an issue before inaking its final recommendation. Although these constraints should be flexible enough to account for scientific uncertainties, they should nevertheless represent serious goals for the Panel's members that coinport with the Agency's perception of an appropriately rapid response. The time constraints would leave unchanged the Panel's duty to reach its decisions by using accepted scientific techniques (trans-science permitting). Panel neinbers should be permitted to discuss the rationale underlying a particular time constraint and to object to any constramts that seein unworkable. The Panel and HWA officials should be able to agree on reasonable time limitations that strike a balance between the needs of good scientific decisionmaking and good regulatory policy.

\section{B. Notice and Comment Requirements}

Because of the trans-scientific nature of the Panel's decisionmaking, HWA should also amend its regulations to facilitate greater public participation at Panel meetings. State law currently mandates a ten-day notice period for all advisory committee meetings, including those of the Panel. ${ }^{216}$ HWA regulations add little more, merely requiring Agency officials to provide "reasonable notice" of upcoming Panel meetings. ${ }^{217}$ Although in practice HWA has voluntarily extended the notice period, sometimes to over a month, the regulations themselves apparently do not mandate anything more than ten days notice, which denies interested persons sufficient time to prepare intelligent, scientifically based presentations for Panel meetings. Due to the complexity of the issues addressed by the Panel, HWA should guarantee interested parties at least one month to prepare evidence for the Panel's consideration. Not only

216. CAL. Gov'T CODE $\S 11125$ (a) (West Supp. 1989).

217. CAL. CoDe of Regs. tit. 22, § 12302(d) (1989). 
would this enable interested parties to accumulate more data and present better reports, it would also help outside parties to be on par with state officials who know further in advance what issues the Panel will address.

In addition, there should be opportunity for comment after the Panel has considered a technical issue. During the Panel's deliberations of technical issues, new ideas and data often come to light for the first time. Although the Panel is supposed to delay consideration of completely new issues until its next meeting, ${ }^{218}$ nothing prohibits it from evaluating new angles to questions already under consideration. Consequently, Panel members as well as interested parties are often confronted with information about which they are not prepared to respond. ${ }^{219}$ HWA should therefore establish a thirty-day waiting period during which the Panel may not forward its final recommendations and listing decisions to HWA and the Governor. In that interval, interested parties could submit responses to only those issues raised at the meeting; no new issues would be permitted. The submitted arguments would be circulated among the Panel meinbers for individual consideration. If a predetermined percentage of the Panel members believe that the responses warrant further consideration by the Panel as a whole, the recommendations or listing decisions would be withdrawn and the issue reconsidered at the next Panel meeting.

\section{Quorum Requirements}

Finally, HWA's current regulations contain quorum requirements that are inadequate to address the needs of either scientific or regulatory decisionmaking. HWA should amend its procedures to require that more than a simple majority of the Panel members be present when the Panel makes its final listing decisions and recommendations. Presently, the Panel need only have six of its twelve inembers in attendance to conduct a binding vote. ${ }^{220}$ In addition, the Panel's decisions, including those regarding the listing of chemicals as known carcinogens or reproductive toxins, need only be approved by a majority of members present at any given meeting. ${ }^{221}$ As a result, under current HWA regulations a chemical can be included on the Governor's list based on the decision of as few

218. Transcript, 1st Meeting, supra note 70, at 7-8 (statement of Robert D. Tousignant, Panel Counse1).

219. In fact, Dr. Ames' "Caveat" establishing the policy of setting de minimis levels of exposure, see supra note 183, may have violated the notice provision, as it was not properly included on the agenda for the third Panel meeting. See Transcript, 3rd Meeting, supra note 68, at 60-61 (statement of Sierra Club representative Mimi Redway) ("[D]iscussing an item like this without putting it on the agenda first and letting people know about it, whether or not you make a decision on it, ... undermines your credibility to a large extent.").

220. CAL. CODE OF Regs. tit. 22, § 12302(e) (1989).

221. Id. 
as four Panel members. ${ }^{222}$

Although HWA regulations require the Panel to contain a wide array of technical experts, they do not ensure that these experts will actually participate in decisions affecting their areas of expertise. In fact, at the meeting during which the Panel's Subpanel on Reproductive Toxicity presented its first proposed standards for identifymg reproductive toxicants, two of the four members of that subcommittee were absent. ${ }^{223}$ The Panel nevertheless went on to discuss the subcommittee's proposal and ultimately to reject it. Later at the same meeting, the Panel recommended ten reproductive toxicants for inclusion on the Governor's list. $^{224}$

HWA argues that its regulations are necessary to accommodate the Panel members, most of whom have other significant professional commitments that may keep them from attending some Panel meetings and may, in fact, force them to resign from Panel membership on relatively short notice. ${ }^{25} \mathrm{~A}$ high quorum requirement might therefore result in the Panel being unable to conduct business, particularly if the Governor has trouble filling any vacancies. Yet, considering the potential impact of the Panel's listing decisions on public health and on the state's economy, it seems unreasonable that only four private individuals could determine which chemicals are regulated by Proposition 65. HWA's present system leaves open the possibility, however unlikely, that eight Panel members may disagree with the voting majority's decision.

HWA regulations should be amended to require that a majority of the entire Panel's membership approve any listing decision or recommendation before it goes to the Goveruor or the Agency. When situations arise in which seven votes for or against a proposal cannot be obtained because of low meeting attendance, the regulations could allow a simple majority of those im attendance, provided that a quorum is present, to pass its findings on to state officials as an interim recommendation, effective only until other Panel members have been able to consider it.

Unfortunately, HWA has already rejected a similar proposal, in which it was suggested that six members approve any Panel decision, on the rather simplistic grounds that "four . . . is not substantially less than six."226 Although this may be true for objective questions of pure science, it is a dangerous way to approach trans-scientific decisionmaking. Considering the impact that the Panel's decisions have on public health and welfare, four votes do seem substantially less than six (or seven).

222. Statement of Reasons, supra note 8, at $\mathbf{3 5 .}$

223. Transcript, 2nd Meeting, supra note 166, at 18, 91 .

224. Id. at 101-65; see also CAL. CODE OF REGS. tit. 22, 12000 (1989).

225. Statement of Reasons, supra note 8, at 35-36.

226. Id. 
This proposal permits the Panel to take interim action before a majority vote of the full Panel takes place. As a result, it strikes a balance between the need for the Panel to conduct business efficiently and the desirability of subjecting Panel recommendations to additional scientific scrutiny.

\section{CONCLUSION}

The amendments to HWA's regulations proposed herein should improve the Panel's performance in providing fair and accurate scientific information and policy advice. The amendments are intended to account for the unique problems posed by trans-scientific decisionmaking by encouraging both good scientific and good regulatory practice. Although the Panel's contribution to effective toxics policies ultimately depends on the dihigence and ability of its members, regulatory reform can reduce the chance that political forces will unduly interfere with its work. These proposals should assist the Panel members in upholding Proposition 65's mandate of providing tough, scientifically sound protection for the public against exposure to hazardous substances. 